\title{
Otizm spektrum bozukluğu olan çocuklar için Sosyal İletişim Kontrol Listesi-Revize'nin Türkçeye uyarlama ve geçerlik-güvenirlik çalışması*
}

\author{
Turkish adaptation and validity-reliability study of the revised Social \\ Communication Checklist for children with autism spectrum disorder
}

\author{
Bahadır İnan ${ }^{1}$, Meral Çilem Ökcün-Akçamuş², Hatice Bakkaloğlu ${ }^{3}$, Seher Yalçın ${ }^{4}$
}

\section{Makale Geçmişi \\ Geliş : 17 Eylül 2019 \\ Düzeltme : 3 Subat 2020 \\ Kabul : 18 Mart 2020}

\section{Makale Türü}

Arastorma Makalesi

\section{Article History}

Received : 17 September 2019

Revised : 3 February 2020

Accepted : 18 March 2020

\begin{abstract}
Öz: Sosyal iletişim ve etkileșim becerileri, Otizm spektrum bozukluğu (OSB) olan çocukların güçlük yaşadıkları bir alandır ve bu güçlükler OSB’nin tanı ölçütlerinden biridir. Dolayısıyla OSB olan çocukların dil ve iletişim becerilerinin gelişimin erken dönemlerinde değerlendirilmesi önemlidir. Bu araştırmada, OSB olan çocuklar için geliştirilmiş Sosyal İletişim Kontrol Listesi-Revize Versiyonu'nun Türkçeye uyarlanması ve Türkçe formunun geçerlik-güvenirliğinin incelenmesi amaçlanmıştır. Çalışma grubunu 294 OSB olan çocuk ve çocukların ebeveynleri ile öğretmenleri oluşturmaktadır. Ölçeğin yapı geçerliği kapsamında Doğrulayıcı Faktör Analizi (DFA) yapılmıştır. Ölçüt geçerliği için Sosyal İletişim Kontrol Listesi -Revize -Okulöncesi Türkçe Versiyonu (SİLKOL-R-OTV) puanları ile Sosyal Yanıtlayıcılık Ölçeği-2-Okul Öncesi Türkçe Formu (SOYÖ-2-OTF) puanları arasındaki ilişkiler incelenmiştir. Ölçeğin güvenirliği ise Cronbach Alfa güvenirlik katsayısı ile incelenmiştir. Analizler sonucunda ebeveynler ve ögretmenler tarafından doldurulan SİLKOL-2-OTV formlarının dört alt ölçekli yapısının model uyum indekslerinin iyi düzeyde olduğu görülmüştür. Bunun yanı sıra SİLKOL-2-OTV puanları ile SOYÖ-2OTF puanları arasında yüksek düzeyde anlamlı ilişkiler olduğu bulunmuştur. SİLKOL-2-OTV ebeveyn ve öğretmen formlarının Cronbach Alfa katsayılarının da yüksek düzeyde olduğu bulunmuştur. Bu bulgular SİLKOL-2-OTV'nin geçerli ve güvenilir bir araç olduğunu göstermektedir.
\end{abstract}

Anahtar Kelimeler: Otizm Spektrum Bozukluğu, Sosyal İletişim ve Etkileşim, Dil, Sosyal İletişim kontrol Listesi, Geçerlik, Güvenirlik

\begin{abstract}
Social communication and interaction skills are areas in which children with autism spectrum disorder (ASD) have difficulties, and these difficulties are among the diagnostic criteria for ASD. Therefore, it is important to assess the language and communication skills of children with ASD in their early stages of development. In this study, it was aimed to adapt the Social Communication ChecklistRevised scale for children with ASD to Turkish and to examine the validity and reliability of the Turkish form. The study group consisted of 294 children with ASD and their parents and teachers. Confirmatory factor analysis (CFA) was performed within the scope of the construct validity of the scale. For criterion validity, the relationships between Social Communication Checklist-Revised-Preschool Turkish Version (SCC-R-PTV) scores and Social Responsiveness Scale-2-Preschool Turkish Form (SRS-2-PTF) scores were examined. The reliability of the scale was examined using Cronbach's alpha reliability coefficient. As a result of the analysis, it was found that the model fit indices of the four subscales of the SCC-RPTV forms filled out by parents and teachers were at good levels. There was also a highly significant relationship between SCC-R-PTV scores and SRS-2-PTF scores. The Cronbach alpha coefficients of the SCC-R-PTV parent and teacher forms were also found to be high. These findings show that the SCC-R-PTV is a valid and reliable tool.
\end{abstract}

Keywords: Autism Spectrum Disorder, Social Communication and Interaction, Language, Social Communication Checklist, Validity, Reliability

\section{Article Type}

Research Article

\footnotetext{
*Bu çalışma ilk yazarın Ankara Üniversitesi Eğitim Bilimleri Enstitüsü’nde tamamladığı yüksek lisans tezinden türetilmiştir.

${ }^{1}$ Ankara Üniversitesi, Eğitim Bilimleri Fakültesi, Özel Eğitim Bölümü, inanb@ankara.edu.tr, ORCID: https://orcid.org/0000-0002-2952-5455

2 Ankara Üniversitesi, Eğitim Bilimleri Fakültesi, Özel Eğitim Bölümü, okcun@ankara.edu.tr, ORCID: https://orcid.org/0000-0003-3297-9711

3 Ankara Üniversitesi, Eğitim Bilimleri Fakültesi, Özel Eğitim Bölümü, hbakkaloglu@ankara.edu.tr, ORCID: https://orcid.org/0000-0002-32269077

${ }^{4}$ Ankara Üniversitesi, Eğitim Bilimleri Fakültesi, Ölçme ve Değerlendirme Bölümü, yalcins@ankara.edu.tr, ORCID: https://orcid.org/00000003-0177-6727
}

Atıf için/To cite this article:

İnan, B., Ökcün-Akçamuş, M. Ç., Bakkaloğlu, H. \& Yalçın, S. (2020). Otizm spektrum bozukluğu olan çocuklar için Sosyal İletişim Kontrol Listesi-Revize'nin Türkçeye uyarlama ve geçerlik-güvenirlik çalışması. Erken Cocukluk Calıs̆malar Dergisi, 4(1), 172-196. doi: http://dx.doi.org/10.24130/eccd-jecs.1967202041193 


\section{SUMMARY}

\section{Introduction}

Autism spectrum disorder (ASD) is a neurological and developmental disorder that occurs in the early stages of development, characterized by impairments in language and communication skills and repetitive behaviors (American Psychiatric Association [APA], 2013). As implied by this definition, early disorders and difficulties in language and communication skills are among the diagnostic features of ASD. As social communication skills and language skills emerge from the early stages of development (Wilkinson, 1998), it is important to assess these skills in early childhood. Accordingly, the assessment of language, social communication, and interaction skills is an important part of diagnostic and educational assessment processes for children with ASD (Paul, 2007). In children with ASD, standardized tests (Trembath \& Iacono, 2016), informative reports, and observation-based measurements (Alak, 2019) are often used to assess social interaction, language, and communication skills. Each of these assessment strategies has strengths and weaknesses relative to the others. Therefore, multi-method and multi-tool approaches are recommended in the assessment of these skill types. However, the number of tools that can be used to assess the social communication and interaction skills of children with ASD in Turkey is quite small. The Social Communication Checklist-Revised (Ingersoll \& Dvortcsak, 2010) was developed to assess the development of children with ASD in the areas of social engagement, expressive language, receptive language, imitation, and play, and to plan interventions based on assessment results. The Social Communication Checklist-Revised can be used to assess multiple areas of social interaction, communication, and language, and to monitor the progress of intervention (Ingersoll \& Wainer, 2013). In this study, it is aimed to adapt the Social Communication Checklist-Revised scale developed for children with ASD into Turkish and to examine the validity and reliability of the Turkish form.

\section{Method}

In order to adapt the checklist, it was translated from English into Turkish, and then it was translated back into English to ensure the accuracy of the translation. After the translation process, the checklist was applied to the parents and teachers of 294 children with ASD in special education and rehabilitation centers overseen by the Ministry of National Education. Criterion sampling, one of the purposeful sampling methods, was used in the selection of the participating children. In criterion sampling, all cases that meet previously determined criteria can be studied. For this purpose, children aged 2-7 years who were diagnosed with and affected by ASD were confirmed with the Gilliam Autism Rating Scale-2-Turkish Version (GARS-2-TV) and permission for their enrollment in the study was granted by their parents. A demographic data form, the Social Communication Checklist-Revised-Preschool Turkish Version (SCC-R-PTV), the GARS-2-TV, and the Social Responsiveness Scale-2-Preschool Turkish Form (SRS-2-PTF) were used as data collection tools in this research. For all participating children, both parents and teachers were asked to complete the four utilized forms. In order to examine the validity and reliability of the SCC-R-PTV, two different 
confirmatory factor analyses (CFAs) were performed for the forms filled out by parents and teachers within the context of construct validity. The relationships between the SRS-2-PTF scores and SCC-R-PTV scores for the criterion validity of the forms completed by parents and teachers were then examined by Pearson product-moment correlation. The internal consistency reliability of the SCC-R-PTV parent and teacher forms was examined using Cronbach's alpha reliability coefficient. CFA was performed with the Mplus 8 package program and other analyses were performed with SPSS.

\section{Results}

As a result of the analyses, the four subscale structures of the scale were confirmed to be similar to the original scale, and the standard path coefficients and factor loads from all items to their subscales were significant. In order to determine the criterion validity, Pearson product-moment correlation analysis was performed since the assumption of normal distribution was provided. As a result of the analyses, it was determined that the relationships between the SCC-R-PTV subscales and the subscales and total scores of the SRS-2-PTF were significant. The internal consistency reliability of the SCC-R-PTV parent and teacher forms was calculated with Cronbach's alpha reliability coefficient. The Cronbach alpha internal consistency coefficients were found to be 0.983 for parents and 0.988 for teachers for the overall SCC-R-PTV. The reliability coefficients of the SCC-R-PTV forms filled out by parents were found to be between 0.889 and 0.945. For the teachers' forms, the coefficients were higher (between 0.933 and 0.979). For inter-rater reliability, the correlation between the SCC-R-PTV parent and teacher forms was examined and it was found to be moderately high. The correlations between SCC-R-PTV parent form and teacher form subscales ranged between 0.532 and 0.644 . In this regard, the study showed close similarity between the adapted version and the original checklist, and the new version was found to be highly reliable. The high correlation between parents and teachers indicates that the items are clear and understandable.

\section{Discussion and Conclusion}

When all analyses are considered, it is concluded that the SCC-R-PTV is a valid and reliable tool for the assessment of the social interaction, communication, and language skills of preschool children with ASD. It is thought that this tool, which can be applied through interviews with parents and teachers in assessing the social interaction, communication, and language skills of children with ASD, can be easily used by researchers in the field due to its shortness and ease of completion. Furthermore, the items in the checklist are aligned with the developmental order of language, social interaction, and communication skills, and the tool is used both in planning and monitoring interventions in international research (Ingersoll and Dvortcsak, 2010). Because of this, the adaptation of this checklist is predicted to be beneficial for practitioners working with children with ASD in Turkey. 


\section{GİRIŞ}

Otizm Spektrum Bozukluğu (OSB), dil ve iletişim becerilerinde bozukluklar ve tekrarlayıcı davranışlarla karakterize olan gelişimin erken dönemlerinde ortaya çıkan nörolojik ve gelişimsel bir bozukluktur (American Psychiatric Association [APA], 2013). Tanımda da görüldüğü gibi dil ve iletişim becerilerinde görülen erken dönem bozukluklar ve güçlükler, OSB'nin tanı özelliklerinden birini oluşturmaktadır. Chawarska ve Volkmar’a göre (2005), OSB olan çocukların ebeveynlerinin çoğunluğunun çocuklarının gelişimine ilişkin ilk endişeleri de genellikle ilk sözcüklerin çıkmamasıyla ve/veya çocuklarında iletişim becerilerinde görülen bir gerilemeyle (sözcüklerin kaybı, göz teması veya başkalarına olan ilginin azalması) ortaya çıkmaktadır. OSB olan çocukların tanı almadan önceki video kayıtlarının ve aile raporlarının incelenmesine dayalı olarak geriye dönük yapılan çalısmalar da OSB olan çocukların yaşamlarının ilk iki yılında sözel olmayan sosyal iletişim becerilerinde ve sözel dil becerilerinde sınırlılıklar ve bozukluklar yaşandığını göstermektedir (Chawarska ve Volkmar, 2005).

OSB olan çocuklarda görülen dil, iletişim ve etkileşim bozuklukları, hem sözel olmayan sosyal iletişim ve etkileşim becerilerinde hem de sözel dil becerilerinde ortaya çıkmaktadır (APA, 2013). OSB olan çocuklarda sözel olmayan sosyal etkileşim becerileri kapsamında, farklı bağlamlara sosyal uyum sağlamada, taklit becerilerinde ve nesneyle oyun ile sembolik oyun becerilerinde güçlükler görülmektedir. Bunun yanı sıra sözel olmayan iletişim becerilerinde, özellikle ortak dikkat başlatma ve yanıtlamada ve iletişim amaçlı ses, bakış ve jestlerin kullanımında güçlükler ve bozukluklar görülebilmektedir (Alanyazın taraması için bkz. Ökcün-Akçamuş, 2016). Sözel olmayan sosyal iletişim ve etkileşim becerilerinin yanı sıra, OSB olan çocuklarda sözel dil gelişiminde de gecikmeler ve bozukluklar görülmektedir. OSB'den etkilenen çocuklardaki dil ve iletişim bozuklukları sözel dilin hiç kazanılmamasından, konuşmadaki sınırlılıklara kadar geniş bir dağılım sergileyebilmekte (Wilkinson, 1998) ve bu bozukluklarda hem niceliksel hem de niteliksel açıdan tanılı çocuklar arasında bireysel farkll11klar görülebilmektedir (Gernsbacher, Geye ve Weismer, 2005).

Sözel olmayan sosyal etkileşim ve iletişim becerileri ile dil becerilerinde görülen bozuklukların ve güçlüklerin gelişimin erken dönemlerinden itibaren ortaya çıkmasından dolayı (Wilkinson, 1998), bu becerilerin erken çocukluk döneminde ayrıntılı olarak değerlendirilmesi önemlidir. Dolayısıyla dil, sosyal iletişim ve etkileşim becerilerinin değerlendirilmesi, OSB olan çocuklar için tanı ve eğitsel değerlendirme süreçlerinin önemli bir parçasıdır (Paul, 2007). OSB olan çocuklarda sosyal etkileşim, dil ve iletişim becerilerinin değerlendirilmesinde genellikle standardize testler (Trembath ve Iacono, 2016), bilgi verici raporlar ve gözleme dayalı ölçümler (Alak, 2019) kullanılmaktadır. Bu 
değerlendirme stratejilerinin her birinin birbirine göre güçlü ve zayıf olduğu yönler bulunmaktadır. $\mathrm{Bu}$ nedenle sosyal etkileşim, iletişim ve dil becerilerinin değerlendirilmesinde çok yöntemli ve çok araçlı bir yaklaşım önerilmektedir. Dilin değerlendirmesinde standardize testler, gözlemler ve bilgi verici raporlar gibi farklı araçların birlikte kullanıldığı çok yöntemli bir yaklaşım ile farklı bağlamlarda dil becerilerini ve dilin kullanımını ölçmede değerli bilgiler elde edilmektedir (Bornstein, Haynes ve Painter, 1998). Dolayısıyla OSB olan çocuklarda dilin değerlendirilmesinde tüm bu dil ve iletişim değerlendirme yaklaşımlarının birlikte kullanılması önerilmektedir (Charman vd., 2005; Sigman ve McGovern 2005; Siller ve Sigman 2002).

Dil ve iletişim becerilerinin değerlendirilmesinde sıklıkla kullanılan norm temelli standardize testler ile çocukların dil ve iletişim becerileri, belirli bir norm grubu ve bundan elde edilen standart puanlarla karşılaştırılmakta (Paul ve Fahim, 2014) ve bu yolla çocukların iletişim gelişiminde önemli bir gecikmenin olup olmadığının belirlenmesi amaçlanmaktadır (Paul, 2008). Standardize testler, çocuğun sosyal iletişim ve dil gelişim düzeyinin, tipik gelişen bireylerle karşılaştırllması ve gelişimsel bir farklılık olup olmadığının belirlenmesi konusunda değerlendirme sürecinde önemli bilgiler sağlamaktadır. Bununla birlikte standart testlerden elde edilen bilgiler, çocukların sosyal etkileşim ve iletişim becerilerine yönelik ayrıntılı bilgi vermemektedir (Trembath ve Iacano, 2016) ve bu testlerden aynı puanı alan iki çocuğun dil yeterlilikleri farklılaşabilmektedir (Acarlar, 2019). Dolayısıyla müdahale süreçlerinde çocukların eğitsel performanslarını belirleme ve amaç belirlemede standardize testlerden sınırlı düzeyde bilgi sağlanabilmektedir. Bunun yanı sıra, çocukların yapılandırılmış ve yabancı bir ortamda değerlendirilmesinden dolayı çocukların iletişim performanslarını tam olarak sergileyememesi gibi bir durumun ortaya çıkması da söz konusudur (Paul, 2007). Çocukların sosyal etkileşim, dil ve iletişim becerilerinin değerlendirilmesinde bu aşamada hem gözlemlerin hem de bilgi verici raporların kullanılması değerli bilgiler sağlamaktadır (Brady ve Keen, 2016).

OSB olan çocuklarda sosyal etkileşim, iletişim ve dil becerilerinin değerlendirilmesinde kullanılan bir diğer yöntem ise doğrudan ve yapılandırılmış gözlemlerdir. Doğrudan gözlemlerde bağlama müdahale edilmez ve çocukların doğal bağlamlarda günlük rutinler içinde ortaya koyduğu iletişim davranışları değerlendirilir. Yapılandırılmış gözlemlerde ise çocukların iletişim davranışlarının ortaya çıkacağı firsatlar yaratılır ve bu yolla iletişim eylemlerini gözlemleme şansı artırılır (Brady ve Keen, 2016). Her iki gözlemde de sıklıkla sürecin video kaydı alınır ve kayıtlar üzerinden operasyonel tanımları yapılmış davranışların ortaya çıkıp çıkmama durumuna göre analizler yapılır (Alak, 2019). Bu süreçte sözel dilin değerlendirilmesi amacıyla ölçüt bağımlı işlemler de kullanılabilir. Bu kapsamda çocuklardan sohbet örneği toplanarak dil örneği analizleri yapılabilir ve 
çocuğun kendisine söylenen bir ifadeyi taklit etmesini içeren taklit işlemleri ile cümle tamamlama gibi hedef yapının ortaya çıkması için yapılandırılan işlemler de kullanılabilir (Acarlar, 2019). Hem gözlemler (Brady ve Keen, 2016) hem de ölçüt bağımlı işlemler, çocukların sosyal etkileşim, dil ve iletişim becerileri üzerine ayrıntılı bilgiler vermektedir (Acarlar, 2019). Bununla birlikte gözleme dayalı değerlendirmeler ve ölçüt bağımlı işlemler sadece değerlendirme yapılan zaman ve ortamdaki performansa ilişkin bilgi vermektedir. Gözlemlere ek olarak bilgi verici raporların kullanılması, çocuğun farklı ortamlarda ve bağlamlarda ortaya koyduğu iletişimsel ve etkileşimsel davranışlarına ilişkin değerli bilgiler sağlamaktadır (Brady ve Keen, 2016).

Bilgi verici raporlar, çocuklarla sıklıkla iletişime geçen ve çocukların farklı bağlamlardaki iletişimsel ve etkileşimsel davranışları konusunda kapsamlı bilgisi olan yetişkinler tarafindan doldurulan dereceleme ölçekleri ve kontrol listeleridir. Bu raporların kullanımıyla çocukların sosyal etkileşim ve iletişim davranışları üzerine maksimum düzeyde bilgi elde edilmesi amaçlanmaktadır (Brady ve Keen, 2016). Bilgi verici raporlar, ebeveynler ya da birincil bakıcılar tarafindan (ör., Türkçe İletişim Davranışları Envanteri [TİGE], Aksu Koç vd., 2008; Sosyal Yanıtlayıcılık Ölçeği-2-Okulöncesi Türkçe Formu (SOYÖ-2-OTF) Bakkaloğlu, Ökçün-Akçamuş, Demir, Bahap-Kudret ve Yalçın, 2019) ya da öğretmenler tarafından doldurulan (SOYÖ-2-OTF, Bakkaloğlu vd., 2019) araçlardan oluşabilir. Her ne kadar bilgi verici raporlar üzerine yanlılık riski taşıdığı ve bu nedenle güvenirliğinin düşük olabileceği gibi konular tartışılsa da (Tomasello ve Mervis 1994) alanyazında yapılan bazı araştırmalar, bilgi verici raporlarla standardize test sonuçlarının birbirleri ile tutarlı olduğunu göstermektedir (Charman 2004; Condouris, Meyer ve Tager-Flusberg, 2003; Stone ve Yoder 2001). Uluslararası alanyazında OSB olan çocukların erken dönemdeki sosyal iletişim ve etkileşim becerilerinin değerlendirilmesinde kullanılabilecek birçok bilgi verici rapora dayalı değerlendirme aracı olmasına rağmen (Bkz. Brady ve Keen, 2016), ülkemizde sınırlı sayıda araç bulunmaktadır. Bunlardan biri olan Türkçe İletişim Davranışları Gelişim Envanteri (TİGE), 8-36 ay arası çocukların erken dönem iletişim ve dil becerilerinin değerlendirilmesi amacıyla kullanılan, aile raporuna dayalı standardize bir envanterdir. Ebeveyn ve öğretmenlerle doldurulabilen SOYÖ-2OTF ise, OSB olan çocukların sosyal yanıtlayıcılıklarının ve katılımlarının ölçülmesinde kullanılabilen DSM-5 ölçütlerine göre hazırlanmış ülkemiz için geçerlik ve güvenirlik çalışmaları tamamlanmış bir ölçektir (Bakkaloğlu vd., 2019). Ülkemizde OSB olan çocukların sosyal etkileşim, iletişim ve dil becerilerini değerlendirebilecek araç sayısının az olmasının yanı sıra, her iki değerlendirme aracının içindeki maddelerin de sosyal iletişim ve etkileşim ile dil becerilerinin gelişim sırasına göre sıralanmaması gibi bir durum da söz konusudur. Dolayısı ile bu araçlardan elde edilen ölçüm sonuçlarını temel alarak eğitsel amaç belirlemede zorluklar olabileceği düşünülmektedir. Sosyal İletişim Kontrol Listesi-Revize (Ingersoll ve Dvortcsak, 2010), uluslararası alanyazında erken 
dönem sosyal iletişim becerilerinin değerlendirilmesi amacıyla sıklıkla kullanılan araçlardan biridir. $\mathrm{Bu}$ kontrol listesi, çocukların sosyal katılım, ifade edici dil, alıcı dil, taklit ve oyun alanlarındaki gelişimlerini değerlendirmek ve müdahaleyi planlamak amacıyla geliştirilmiştir. Kontrol listesinin kısa olması ve birden fazla sosyal iletişim alanını aynı anda değerlendirmesi nedeniyle araştırmacılar tarafından da hızla değerlendirme aracı olarak kullanılmaya başlanmıştır (Ingersoll ve Wainer, 2013). Sosyal İletişim Kontrol Listesi-Revize, kısa ve verimli bir araç olmasının yanı sıra sosyal etkileşim, iletişim ve dil gibi birden fazla alanı değerlendirmek için ve müdahalenin ilerlemesini izlemek için de kullanılabilmektedir (Ingersoll ve Wainer, 2013). Bu aracın Türkçe versiyonun hazırlanmasının ve ülkemize uyarlanmasının, ülkemizde OSB olan çocukların erken dönem sosyal etkileşim, iletişim ve dil becerilerini ebeveyn ve öğretmen raporlarına dayalı olarak, ayrıntılı şekilde değerlendiren araç sayısının sınırlı olmasından ve mevcut araçların bu becerilerin gelişim aşamalarına göre sıralanmış maddeleri içermemesinden dolayı, ülkemiz alanyazınına ve müdahale uygulamalarına katkı sağlayacağına inanılmaktadır. Bu çalışmada OSB olan çocuklar için geliştirilen Sosyal İletişim Kontrol Listesi-Revize ölçeğinin Türkçeye uyarlanması ve Türkçe Formunun geçerlik-güvenirlik çalışmasının yapılması amaçlanmaktadır. Araştırmada "OSB olan çocukların erken sosyal etkileşim, iletişim ve dil becerilerinin değerlendirilmesi amacıyla geliştirilen Sosyal İletişim Kontrol ListesiRevize-Okulöncesi Türkçe Versiyonu (SİLKOL-R-OTV) geçerli ve güvenilir midir?” sorusuna yanıt aranmıştır.

\section{YÖNTEM}

\section{Katılımc1lar}

Araştırmanın katılımcıları, Milli Eğitim Bakanlığı bünyesinde 25 farklı ilde özel özel eğitim ve rehabilitasyon merkezlerinde eğitim alan, hastanelerin ilgili birimlerinden tanı almış, OSB olan 2-7 yaş arası (Ort=4.82, Ss=1.48) 294 çocuktan oluşmaktadır. Katılımcı çocukların seçiminde amaçlı örnekleme yöntemlerinden ölçüt örneklemesi kullanılmıştır. Ölçüt örneklemesinde, araştırmanın amacına göre daha önce belirlenmiş olan ölçütleri karşılayan çalısma grubu ile çalışılmaktadır. Araştırmanın ölçütleri, araştırmacı tarafindan oluşturulmakta ya da daha önceden belirlenmiş olan belirli ölçütler kullanılmaktadır (Marshall ve Rossman, 2016). Bu amaçla bu araştırmada katılımcı çocukların belirlenmesinde çocukların a) 2-7 yaş aralığında olması ve b) OSB tanısının GOBDÖ2-TV ile doğrulanması olmak üzere iki ölçüt belirlenmiştir. Bu iki ölçütü karşılayan OSB tanılı çocuğa sahip ve araştırmaya katılım için gönüllü olan 354 ebeveyn ve 380 öğretmenden veri toplanmıştır. Hem ebeveyn hem de öğretmen formları için z puanları hesaplanıp tek değisskenli uç değerler incelenerek veri grubundan çıkarıldıktan sonra, kalan 321 çocuk çifti için çok yönlü uç 
değerler ve tesadüfí olmayan kayıp veriler incelenip düzenlenmiştir. OSB olan çocukların tanısını doğrulamak için kullanılan GOBDÖ-2-TV, Otistik Bozukluk İndeksi'ne (OBİ) göre 69 puan ve altında alan çocuklar OSB görülme olasılığı olmadığı için 27 form çalışma dışında bırakılmıştır. Sonuç olarak 294 OSB tanılı çocuğun ebeveyninden ve öğretmeninden veri toplanmıştır. Çalışmaya katılan çocuklara ilişkin demografik bilgiler Tablo 1'de verilmiştir. Çalışma grubunun devam ettiği eğitim kurumları illere göre Amasya (2), Ankara (92), Antalya (12), Aydın (9), Bursa (1), Denizli (4), Diyarbakır (6), Eskişehir (9), Isparta (5), İstanbul (36), İzmir (18), Karabük (5), Kastamonu (9), Kurıkkale (1), Kurklareli (7), Kocaeli (1), Konya (14), Malatya (6), Manisa (1), Muğla (2), Sakarya (3), Samsun (22), Van (1), Yalova (2) ve Yozgat (1) biçiminde dağılım göstermektedir.

Tablo 1. OSB olan çocukların demografik özellikleri

\begin{tabular}{|c|c|c|c|}
\hline Değişkenler & & $\mathbf{N}$ & $\%$ \\
\hline \multirow{7}{*}{ Çocuğun yaşı } & 2 yaş & 12 & 4.1 \\
\hline & 3 yaş & 48 & 16.3 \\
\hline & 4 yaş & 75 & 25.5 \\
\hline & 5 yaş & 64 & 21.8 \\
\hline & 6 yaş & 35 & 11.9 \\
\hline & 7 yaş & 60 & 20.4 \\
\hline & Toplam & 294 & 100 \\
\hline \multirow{3}{*}{ Çocuğun cinsiyeti } & $\mathrm{K}_{12}$ & 44 & 15.0 \\
\hline & Erkek & 250 & 85.0 \\
\hline & Toplam & 294 & 100 \\
\hline \multirow{3}{*}{ Otizm derecesi (Ebeveyn verisine göre OBİ) } & Hafif (70-84) & 91 & 30.95 \\
\hline & Ağır $(85+)$ & 203 & 69.05 \\
\hline & Toplam & 294 & 100 \\
\hline \multirow{3}{*}{ Otizm derecesi (Öğretmen verisine göre OBI) } & Hafif (70-84) & 86 & 29.25 \\
\hline & Ağır $(85+)$ & 208 & 70.75 \\
\hline & Toplam & 294 & 100 \\
\hline \multirow{5}{*}{ Çocuğun tanı konma yaşı } & $0-2$ yaş & 85 & 28.9 \\
\hline & $2-3$ yaş & 118 & 40.1 \\
\hline & 3 yaş ve üzeri & 56 & 19.1 \\
\hline & Yanit yok & 35 & 11.9 \\
\hline & Toplam & 294 & 100 \\
\hline \multirow{4}{*}{ Çocuğun özel eğitim hizmeti alma süresi } & 2 yıldan az & 173 & 58.8 \\
\hline & 2 y1ldan fazla & 103 & 35.1 \\
\hline & Yanit yok & 18 & 6.1 \\
\hline & Toplam & 294 & 100 \\
\hline \multirow{5}{*}{ Çocuğun özel eğitim almaya başlama yaşı } & 2 yaştan önce & 77 & 26.2 \\
\hline & $2-3$ yaş & 131 & 44.6 \\
\hline & 3 yaştan sonra & 62 & 21.1 \\
\hline & Yanit yok & 24 & 8.1 \\
\hline & Toplam & 294 & 100 \\
\hline
\end{tabular}

Tablo 1'de görüldüğü üzere, yaşları 2-7 yaş arasında dağıllım gösteren katılımcıların, 250'si erkek, 44’ü kız çocuklardan oluşmaktadır. Bu çalışmada OSB olan erkek çocukların oranı, kız çocuklara göre yaklaşık 6 kat olarak belirlenmiştir. Alanyazına bakıldığında ise erkeklerde OSB görülme sıklı̆̆ının kadınlara oranla yaklaşık 5 kat fazla olduğu öne sürülmektedir (Baio vd., 2018; Fombonne, 
2009). Sonuç olarak bu çalışmanın katılımcılarının cinsiyet oranının, alanyazın doğrultusunda beklenen oranlara yakın düzeyde olduğu düşünülmektedir.

OSB olan çocuklar için form dolduran öğretmen ve ebeveynlere ilişkin demografik bilgiler incelendiğinde, form dolduran ebeveynlerin yaşlarının 21 ile 45 yaş arasında dağılım gösterdiği ve çoğunluğunun 31-40 (152 ebeveyn) yaş arasında olduğu görülmüştür. Formu dolduran ebeveynlerin \%72'si (213 kişi) annelerden oluşmaktadır. Eğitim düzeylerine göre ele alındığında, ebeveynlerin eğitim düzeyleri okuryazar olmamak ile lisansüstü eğitim arasında dağılım göstermekte ve form dolduran ebeveynlerin çoğunluğunu üniversite mezunu ebeveynler (\%34.7, 102 ebeveyn) oluşturmaktadır. Benzer bir biçimde katılımcılar için form dolduran öğretmenlerin de çoğunluğunu (\%72.1, 212 öğretmen) kadın öğretmenler oluşturmaktadır. Eğitim düzeylerine göre ele alındığında öğretmenlerin eğitimleri lisans ve lisansüstü eğitim arasında dağılım göstermekte ve katılımcı öğretmenlerin \%86.1’i (253 öğretmen) lisans derecesinden mezun öğretmenlerden oluşmaktadır. Öğretmenler, farklı lisans programlanından mezun (özel eğitim [117 kissi], sınıf öğretmenliği [29 kişi], okul öncesi öğretmenliği [79 kişi] ve diğer [55 kişi]) olmakla birlikte, öğretmenlerin çoğunluğu özel eğitim alanından mezundur.

\section{Veri Toplama Araçları}

\section{Demografik Bilgi Formu}

Araştırmacılar tarafından ebeveynler ve öğretmenler için iki farklı Demografik Bilgi Formu geliştirilmiştir. Ebeveynler için hazırlanan form, araştırma grubuna katılan çocuğun yaşı, cinsiyeti, kardeş sahibi olma durumu, tanı konma yaşı, ilk olarak ne zaman yürüdüğü, iletişim kurarken sözcük kullanıp kullanmadığı, iletişim kuruyorsa ilk olarak ne zaman sözcükler kullandığı, ebeveynin eğitim durumu, özel eğitim konusunda eğitim alıp almadığı, çocuğa başka bakım veren bir kişinin olup olmadığı gibi bilgileri ve çocuğun gelişim özelliklerine ilişkin soruları içermektedir. Öğretmenler için hazırlanan form ise öğretmenin mezuniyet alanı, özel eğitim alanındaki hizmet süresi, bir eğitim günü içinde çocukla ne kadar süre geçirdiği, eğitim-öğretim yaparken güçlük çekip çekmediğine ilişkin soruları içermektedir.

\section{Gilliam Otistik Bozukluk Derecelendirme Ölçĕ̆i (GOBDÖ-2-TV)}

Gilliam Otistik Bozukluk Derecelendirme Ölçeği-2 (GOBDÖ-2 [Gilliam Autism Rating Scale-2]) otistik bozukluğu karakterize eden davranışları sergileyen 3 ile 23 yaş arasındaki kişilerin tarama ve tanılama amaçlı değerlendirilmesinde kullanılan bir derecelendirme ölçeğidir (Gilliam, 2006). 
GOBDÖ-2-TV'de yer alan maddeler DSM-IV-TR (2000) OSB tanı özellikleri temelinde geliştirilmiştir (Diken, Ardıç, Diken ve Gilliam, 2012). Ölçeğin Türkçeye uyarlama, geçerlik ve güvenirlik çalışmaları Diken ve diğerleri (2012) tarafından gerçekleștirilmiştir. GOBDÖ-2-TV’nin Stereotip Davranışlar, İletişim ve Sosyal Etkileşim ile ilgili üç alt ölçeği bulunmaktadır. Her bir alt ölçek 14 madde içermekte, ölçek toplamda ise 42 maddeden oluşmaktadır. Maddeler "hiç gözlenmedi (0)”, “nadiren gözlendi (1)”, “bazen gözlendi (2)” ve “sılklıkla gözlendi (3)” şeklinde dörtlü dereceleme ile puanlanmaktadır. GOBDÖ-2-TV ile yapılan değerlendirmelerin sonucunda Otistik Bozukluk İndeksi (OBİ) puanı elde edilmekte ve bu puan ile çocukların OSB'den etkilenme düzeylerine bakılmaktadır. Buna göre 69 ve altı "OSB görülme olasılı̆̆1 yok”, 70-84 arası "OSB görülme olasılığı var”, “85 ve üzeri OSB görülme oldukça yüksek” şeklinde belirlenmektedir. Ölçeğin uyarlama çalışmasında Diken ve diğerleri (2012), Türkçe versiyonunun iç tutarllık katsayılarının .77-.85 arasında değiştiğini, (sosyal etkileşim $\alpha=.79$, iletişim $\alpha=.77$, stereotip davranışlar $\alpha=.85)$ ölçek toplamında ise .88 olduğunu, doğrulayıcı faktör analizleri sonuçlarında ölçeğin faktör yapisına ilişkin model uyumunun iyi düzeyde olduğunu $\left(\mathrm{X}^{2}=1730.08, \mathrm{Sd}=813\right.$, $\mathrm{X}^{2} / \mathrm{Sd}=2.13$, CFI=.89, RMSA=.071) bulmuşlardır. Bu çalışmada da katılımcı çocukların GOBDÖ2-TV' den aldıkları puanların iç tutarlılığı Cronbach alfa katsayısı ile hesaplanmış, ebeveynler için bu değerlerin .80 ile .88 arasında olduğu (sosyal etkileşim $\alpha=.88$, iletişim $\alpha=.80$, stereotip davranışlar $\alpha=.86$, ölçek toplamı $\alpha=.85$ ), öğretmenler için ise iç tutarlılık katsayısının .85 ile .91 arasında değiştiği (sosyal etkileşim $\alpha=.91$, iletişim $\alpha=.85$, stereotip davranışlar $\alpha=.87$, ölçek toplam $\alpha=.83$ ) bulunmuştur.

\section{Sosyal İletişim Kontrol Listesi-Revize-Okulöncesi Türkçe Versiyonu (SİLKOL-R-OTV)}

Sosyal İletişim Kontrol Listesi-Revize versiyonu, OSB olan çocuklarda sosyal iletişim ve etkileşim becerilerinin değerlendirilmesi amacıyla Ingersoll ve Dvortcsak (2010) tarafından geliştirilmiştir. Kontrol listesi ilk olarak 18. ay ile 6 yaş arası çocukların sosyal katılım, taklit ve oyun becerilerinin ebeveyn aracılı doğal gelişimsel davranışsal müdahalelerin bir parçası olarak amaç alımı ve gelişimin değerlendirilmesi süreçlerinde kullanılmak üzere geliştirilmiştir. Daha sonrasında kısa ve verimli olması ve birden fazla sosyal iletişim alanını aynı anda değerlendirmesi nedeniyle araştırmacılar tarafından da değerlendirme aracı olarak kullanılmaya başlamıştır (Ingersoll ve Wainer 2013). Kontrol listesi; sosyal katılıma yönelik 15, ifade edici dile yönelik 30, alıcı dile yönelik 8 ve taklit ile oyun becerilerine yönelik 17 madde olmak üzere toplam 70 madde içermektedir. Yetişkinler, kontrol listesini OSB olan çocukların maddedeki ilgili beceriyi kullanma durumlarına göre "nadiren ya da henüz değil (1 puan), bazen ama sürekli değil (2 puan) ve genellikle, zamanının en az \% $\%$ ’’ i (3 puan)" şeklinde puanlamaktadır. Kontrol listesinden sosyal katılım için 15 ile 45, ifade edici dil 
için 30 ile 90, alıcı dil için 8 ile 24, taklit/oyun için 17 ile 51 ve toplam puan için 70 ile 210 arasında puan alınabilmektedir. Aracın geliştirilmesinde erken çocukluk döneminde okul öncesi yaşlardaki sosyal etkileşim, iletissim ve dil becerilerinin gelişimsel sırası temel alınmıştır ve maddeler olumlu biçimde (ör., tercih eder mi, katılır mı, taklit eder mi...) yazılmıştır. Kontrol listesinin orijinal formunun güvenirlik çalışmasında hem ebeveynler hem de terapistler tarafından doldurulan formlar için Cronbach alfa iç tutarlık katsayısı hesaplanmıştır. Analizler sonucunda ebeveynlerin doldurdukları formlarda iç tutarlılık katsayısının sosyal katılım alt alanı için .870, dil alt alanı için .959, taklit ile oyun alt alanı için .891 toplamda ise .967 olduğu bulunmuştur. Terapistler tarafından doldurulan formlarda ise iç tutarlılık katsayısının sosyal katılım alt alanı için .870, dil alt alanı için .958 ve taklit ile oyun alt alanı için .714 olduğu, toplam puan için ise .960 olduğu bulunmuştur (Wainer, Berger ve Ingersoll, 2017).

Sosyal İletişim Kontrol Listesi-Revize aracının Türkçeye çevirisi araştırmacı ekip tarafından gerçekleştirilmiştir. Bu süreçte ölçeğin İngilizce formu, araştırma alanını ve İngilizce ile Türkçe dillerini iyi derecede bilen beş farklı araştırmacı tarafından Türkçeye çevrilmiştir. Akademisyenlerin Türkçeye çevirdikleri beş ayrı kontrol listesi üzerinde uzmanların yaptı̆̆ı düzeltme ve önerilerle birlikte tek bir Türkçe form elde edilmiştir. Ortaya çıan Türkçe form, İngilizce ve Türkçe dillerini iyi bilen başka bir alan uzmanı tarafından tekrar İngilizceye çevrilmiştir. Geri çeviri sonrasında ölçeğin Türkçe formunun İngilizce formuna benzer olduğu görülmüştür. Türkçe-İngilizce ve İngilizce-Türkçe çevirileri tamamlanan çeviri formunun ölçek maddeleri tekrar incelenerek Sosyal İletişim Kontrol Listesi-Revize-Okulöncesi Türkçe Versiyonunun (SİLKOL-R-OTV) son hali oluşturulmuştur. SİLKOL-R-OTV'nin geçerlik ve güvenirliğine ilişkin elde dilen sonuçlar Bulgular bölümünde sunulmuştur.

\section{Sosyal Yanıtlayıcılık Ölçeği-2-Okulöncesi Türkçe Formu (SOYÖ-2-OTF)}

Sosyal Yantlayıcılık Ölçeği-2 (Social Responsiveness Scale-2 [SRS-2] Constantino 2002; Constantino ve Gruber, 2012), 2-89 yaş arası OSB olan bireylerde sosyal iletişimsel becerilerinde görülen sınırlılıkların ve tekrarlayıcı davranışların değerlendirilmesinde kullanılan, yapı olarak DSM5 ölçütleri ile uyumlu ve kanıta dayalı bir ölçme aracıdır. Sosyal Yanıtlayıcılık Ölçeği-2 (SYÖ-2) OSB’ye ilişkin tanı özellikleri olan sosyal farkındalık (8), sosyal biliş (12), sosyal iletişim (22), sosyal motivasyon (11) ve sınırlı ilgi alanları ve tekrarlayıcı davranışlara (12) ilişkin beş alt ölçekten ve toplam 65 maddeden oluşmaktadır. Bu ölçek ile ebeveynler ve öğretmenler/terapistler, çocuklarının/öğrencilerinin davranışlarını 1'den (doğru değil) 4'e (hemen hemen her zaman doğru) doğru puanlayarak derecelendirmektedir. Ölçek el kitabındaki puanlama anahtarına göre 
ebeveynlerin kodlamaları tekrar puanlanmaktadır. Bu puanlamada ebeveynlerin verdikleri 4 puan 3, 3 puan 2, 2 puan 1 ve 1 puan 0 puana dönüştürülmektedir ve tersine puanlanan maddelerin $(3,7$, $11,12,15,17,21,22,26,32,38,40,43,45,48,52,55)$ puanlar1 el kitabındaki puanlama anahtarına göre tersine çevrilmektedir. Ölçek toplamından 0-195 arasında puan elde edilebilmektedir. Ölçekten elde edilen puanlar attıkça hem sosyal iletişim becerilerinde görülen bozukluklar hem de tekrarlayıcı davranışlar için alınan puanlar artmaktadır (Constantino ve Gruber, 2012). Ölçeğin Türkçe geçerlik güvenirlik çalışması Bakkaloğlu ve diğerleri (2019) tarafından gerçekleştirilmiştir. Yap1 geçerliği için yapılan Doğrulayıcı Faktör Analizi (DFA) sonucunda modelin uyum indekslerinin $\left(\mathrm{X}^{2}=4114.916, \mathrm{Sd}=2005, \mathrm{X}^{2} / \mathrm{Sd}=2.05, \mathrm{RMSEA}=0.061, \mathrm{CFI}=0.80\right)$ iyi düzeyde olduğu bulunmuştur. Ölçüt geçerliği ise GOBDÖ-2-TV ile gerçekleştirilmiş ve alt ölçekleri ile olan korelasyonlarının orta ve yüksek düzeyde olduğu (iletişim .59, sosyal etkileşim .76, stereotip davranışlar .63) bulunmuştur. Güvenirlik analizlerinde ise ölçekteki alt ölçeklerin Cronbach alfa iç tutarlılık katsayıları sosyal farkındalık $\alpha=.59$, sosyal biliş $\alpha=.72$, sosyal iletişim $\alpha=.87$, sosyal motivasyon $\alpha=.79$ ve sınırlı ilgi alanları ve tekrarlayıcı davranışlar $\alpha=.80$ düzeyindedir. Ölçeğin toplamında ise Cronbcah alfa iç tutarlık katsayısı $\alpha=.95$ düzeyindedir. Çalışmada OSB olan bireylerin sosyal iletişim becerilerini değerlendirmek üzere, araştırmacılardan izin alınarak kullanılan aracın ebeveynler ve öğretmenler tarafindan ayrı ayrı doldurulması sağlanmıştır.

\section{Verilerin Analizi}

Verilerin analiz aşamasında öncelikle SİLKOL-R-OTV toplam puanları ve faktör puanları için ortalama, standart sapma, en büyük (maksimum) ve en küçük (minimum) puanlar incelenmiştir. Daha sonra araştırmada kullanılan tüm ölçeklerin alt ölçek ve toplam puanları alınmıştır. GOBDÖ2-TV'nin toplam puanlarından standart puanlar, standart puanlarından ise Otistik Bozukluk İndeksi (OBI) hesaplanmıştır. Analizler öncesinde OSB olan çocukların tanısını doğrulamak için kullanılan GOBDÖ-2-TV'nin, (OBİ) göre 69 puan ve altında alan çocuklar (27) OSB görülme olasılığ1 olmadığı için çalışma dışında bırakılmıştır. Sonrasında tüm ölçeklerden elde edilen veriler için kayıp değerler, uçdeğerler incelenmiş ve veriler temel varsayımlar açısından kontrol edilmiştir. Bunun için öncelikle ölçeklerden elde edilen puanların çarpıklık, basıklık katsayıları, standart sapmaları incelenmiştir. Tek yönlü uç değerler, standart Z puan dönüşümü kullanılarak incelenmiş ve \pm 3’ün üstünde kalan değerler ile çok yönlü uç değerler ise mahalanobis uzaklığı ile saptanmış ve uç değerler veri grubundan çıkarılmıştır. Sonuç olarak 294 çocuk için ebeveyn ve öğretmen verileri kalmış ve bu çocuklardan çalışma grubu oluşturulmuştur. Ardından ebeveyn ve öğretmenlerden alınan bilgilere göre OSB olan çocukların ölçeklerden aldıkları puanların ortalama, standart sapma, minimum ve maksimum değerleri hesaplanmıştır (Bkz., Tablo 2). Bu betimsel istatistiklerin yanı 
sıra tüm ölçümler için çarpıklık ve basıklık katsayıları incelenmiş, iki katsayının da “-2” ile “+2” arasında olduğu, yani normal dağılım varsayımını karşıladığı görülmüştür (George ve Mallery, 2010).

Araştırmanın amacı doğrultusunda SİLKOL-R-OTV'nin geçerlik ve güvenilirliğinin incelenmesi amacıyla yapı geçerliği kapsamında ebeveynlerin ve öğretmenlerin doldurdukları formlar için iki farklı Doğrulayıcı Faktör Analizi (DFA) yapılmıştır. Ardından ebeveyn ve öğretmenler tarafından doldurulan formların ölçüt geçerliği için SOYÖ-2-OTF puanları ile SİLKOL-R-OTV puanları arasındaki ilişkiler Pearson Momentler Çarpımı korelasyon analizi ile incelenmiştir. SİLKOL-ROTV'nin ebeveyn ve öğretmen formunun iç tutarlllık güvenirliği; alt faktörler ve tüm ölçek için Cronbach alfa güvenirlik katsayısı ile hesaplanmıştır. DFA, Mplus 8 paket programı ile diğer analizler ise SPSS paket programı kullanılarak yapılmıştır.

\section{BULGULAR}

Çalışmada öncelikle OSB olan çocuklarda ebeveyn ve öğretmen formlarının SİLKOL-R-OTV toplam ve alt alan puanları, SOYÖ-2-OTF alt ölçek ve toplam puanları ile GOBDÖ-2-TV'den elde edilen OBİ puanlarına ilişkin betimsel istatistikler incelenmiştir. İlgili betimsel istatistikler Tablo 2'de sunulmuştur.

Tablo 2. Ebeveynlerden ve öğretmenlerden alınan bilgilere göre SİLKOL-R-OTV, SOYÖ-2-OTF ve GOBDÖ-2-TV puanlarına ilişkin betimsel değerler

\begin{tabular}{|c|c|c|c|c|c|c|c|c|c|}
\hline \multirow{2}{*}{\multicolumn{2}{|c|}{ Alt Ölçekler }} & \multicolumn{2}{|c|}{$\mathrm{N}$} & \multicolumn{2}{|c|}{ Ort } & \multicolumn{2}{|c|}{ Ss } & \multicolumn{2}{|c|}{ En küçük-En büyük } \\
\hline & & $E$ & $\ddot{\mathrm{O}}$ & $\mathrm{E}$ & $\ddot{\mathrm{O}}$ & $\mathrm{E}$ & $\ddot{\mathrm{O}}$ & $\mathrm{E}$ & $\ddot{\mathrm{O}}$ \\
\hline \multirow{5}{*}{$\begin{array}{l}\text { SİLKOL-R- } \\
\text { OTV }\end{array}$} & SK & 294 & 294 & 32.57 & 29.08 & 7.93 & 9.32 & $15-45$ & $15-45$ \\
\hline & $\dot{\mathrm{I}} \mathrm{AD}$ & 294 & 294 & 54.85 & 51.63 & 15.57 & 17.21 & $30-90$ & $30-90$ \\
\hline & $\mathrm{AD}$ & 294 & 294 & 17.53 & 15.77 & 4.69 & 5.20 & $8-24$ & $8-24$ \\
\hline & $\mathrm{TO}$ & 294 & 294 & 33.32 & 30.64 & 8.79 & 9.48 & $17-51$ & $17-51$ \\
\hline & Toplam & 294 & 294 & 141.28 & 108.73 & 32.43 & 37.79 & $73-203$ & $71-209$ \\
\hline \multirow{6}{*}{ SOYÖ-2-OTF } & $\mathrm{SF}$ & 294 & 294 & 10.77 & 12.65 & 4.85 & 4.51 & $0-24$ & $1-24$ \\
\hline & SB & 294 & 294 & 17.57 & 19.64 & 5.84 & 6.27 & $0-34$ & $3-35$ \\
\hline & Sİ & 294 & 294 & 29.04 & 32.81 & 11.09 & 12.42 & $3-60$ & $4-60$ \\
\hline & $\mathrm{SM}$ & 294 & 294 & 14.91 & 17.22 & 6.12 & 6.58 & $1-32$ & $1-33$ \\
\hline & SİTD & 294 & 294 & 14.14 & 14.50 & 6.85 & 7.20 & $0-36$ & $0-36$ \\
\hline & Toplam & 294 & 294 & 86.90 & 97.21 & 29.76 & 33.54 & $4-186$ & $9-188$ \\
\hline \multirow{2}{*}{$\begin{array}{c}\text { GOBDÖ- } \\
\text { 2-TV }\end{array}$} & Hafif (70-84 OBI) & 91 & 86 & 85.19 & 85.89 & 5.53 & 5.67 & $70-84$ & $70-83$ \\
\hline & A ğır (85+OBI) & 203 & 208 & 100.60 & 101.91 & 12.36 & 11.66 & $85-138$ & $85-140$ \\
\hline
\end{tabular}

E: Ebeveyn; Ö: Öğretmen; SİLKOL-R-OTV: Sosyal İletişim Kontrol Listesi-Revize-Okulöncesi Türkçe Versiyonu; E: Ebeveyn; Ö: Öğretmen; SK: Sosyal Katılım; İED: İfade Edici Dil; AD: Alıcı Dil; TO: Taklit/Oyun; SOYÖ-2-OTF: Sosyal Yanıtlayıc1lık Ölçeği-2-Okul Öncesi Türkçe Formu; SF: Sosyal Farkındalı;; SB: Sosyal Biliș; Sİ: Sosyal İletișim; SM: Sosyal Motivasyon; SíTD: Sınırlı İlgi Alanı ve Tekrarlayıcı Davranışlar; GOBDÖ-2-TV: Gilliam Otistik Bozukluk Derecelendirme Ölçeği-2-Türkçe Versiyonu; OBİ: Otizm Bozukluk İndeksi

Tablo 2'de verilen istatistiklerin yanı sıra tüm ölçeklerden elde edilen puanlarının çarpıklık ve basıklık katsayıları incelenmiş ve bu puanların basıklık ve çarpıklık katsayılarının “-2” ile "+2” arasında olduğu, yani normal dağılım varsayımını karşıladığı (George ve Mallery, 2010) 
bulunmuştur. Betimsel istatistiklerin incelenmesinin ardından ölçeğin geçerlik güvenirlik analizleri yapılmıştır.

\section{Sosyal İletişim Kontrol Listesi-Revize-Okulöncesi Türkçe Versiyonunun Geçerlik Analizleri}

SİLKOL-R-OTV'nin geçerliğinin incelenmesi amacıyla yap1 geçerliğine ve ölçüt geçerliğine bakılmıştır.

\section{Yap1 geçerliği}

SİLKOL-R-OTV'nin yap1 geçerliği analizleri kapsamında ebeveyn ve öğretmenlerin kontrol listesine verdikleri yanıtlardan yararlanarak aracın orijinal formundaki yapının Türk kültürüne de uygun olma durumu incelenmiştir. Bu amaçla ebeveynlerin ve öğretmenlerin doldurdukları formlar için iki farklı Doğrulayıcı Faktör Analizi (DFA) yapılmıştır. DFA, diğer faktör analizlerinden farklı olarak, ilgili değişkenler arasındaki ilişki hakkında önceden belirlenmiş olan yapının test edilmesini sağlamaktadır (Büyüköztürk, 2002). Model uygunluğunun belirlenmesinde çeşitli uyum iyiliği indeksleri ve açıklamış oldukları istatistiksel fonksiyonlar bulunmaktadır (Erdoğan, Bayram ve Deniz, 2007). Bu çalışmada, ki-karenin serbestlik derecesine oranı (X2/sd), yaklaşık hataların ortalama karekökü (Root Mean Square Error of Approximation; RMSEA), karşılaştırmalı uyum indeksi (Comperative Fit Index; CFI) ve Tucker Lewis İndeksi (Tucker Lewis Index; TLI) dikkate alınmıştır (Brown, 2014). Bu çalışma kapsamında söz konusu uyum indekslerinin normal değer aralığı, kabul edilebilir değer aralığ1 ve ebeveynler ve öğretmenler tarafindan doldurulan formlar için SİLKOL-R-OTV verileri ile yapılan DFA sonucunda ulaşılan değerler Tablo 3'de verilmiştir.

Tablo 3. SİLKOL-R-OTV'nin uyum indeksi değerleri

\begin{tabular}{|c|c|c|c|c|}
\hline \multirow{2}{*}{ Uyum İndeksi } & \multirow{2}{*}{ Mükemmel Uyum } & \multirow{2}{*}{ Kabul Edilebilir Değer } & \multicolumn{2}{|c|}{ SİLKOL-R-OTV Sonuçları } \\
\hline & & & Ebeveyn & Öğretmen \\
\hline $\mathrm{X}^{2} / \mathrm{df}$ & $0 \leq \mathrm{X}^{2} / \mathrm{df} \leq 2$ & $2 \leq \mathrm{X}^{2} / \mathrm{df} \leq 3$ & 2.19 & 2.23 \\
\hline RMSEA & $0 \leq \mathrm{RMSEA} \leq 0,05$ & $0,05 \leq \mathrm{RMSEA} \leq 0,10$ & 0.068 & 0.069 \\
\hline CFI & $0,95 \leq \mathrm{CFI} \leq 1.00$ & $0,90 \leq \mathrm{CFI} \leq 0,95$ & 0.916 & 0.954 \\
\hline TLI & $0,95 \leq \mathrm{TLI} \leq 1.00$ & $0,90 \leq \mathrm{TLI} \leq 0,95$ & 0.913 & 0.953 \\
\hline
\end{tabular}

(Byrne, 2016; Hooper vd., 2008; Kline, 2015; Meyers, Gamst ve Guarino, 2006; Schermelleh-Engel, Moosbrugger ve Müller, 2003)

Çalışmada SİLKOL-R-OTV’nin yapı geçerliğini belirlemek amacıyla yapılan DFA sonucuyla uyum iyiliği değerleri incelendiğinde ki-karenin serbestlik derecesine oranın ebeveyn formu $(5121.967 / 2339=2.19)$ ve öğretmen formu $(5226.578 / 2339=2.23)$ için kabul edilebilir değerler arasında ve manidar olduğu görülmüştür $(\mathrm{p}<.01)$. Diğer bazı uyum iyiliği değerlerine bakıldığında, hem ebeveyn formunda (RMSEA: .068; CFI: .916; TLI: .913) hem de öğretmen formunda 
(RMSEA: .069; CFI: .954, TLI: .953) modelin iyi uyuma sahip olduğu görülmektedir (Çokluk, Şekercioğlu ve Büyüköztürk, 2012). DFA sonucunda, ebeveyn ve öğretmen formuna göre SİLKOL-R-OTV'nin dört alt faktöründeki maddelerin faktör yük değerleri Tablo 4’te sunulmuştur.

Tablo 4. SİLKOL-R-OTV'nin ebeveyn ve öğretmen formu için DFA sonucunda elde edilen faktör yükleri

\begin{tabular}{|c|c|c|c|c|c|c|c|c|}
\hline & \multicolumn{2}{|c|}{ Sosyal Katılım } & \multicolumn{2}{|c|}{ İfade Edici Dil } & \multicolumn{2}{|c|}{ Alic1 Dil } & \multicolumn{2}{|c|}{ Taklit/Oyun } \\
\hline & $\mathrm{E}$ & $\ddot{O}$ & $\mathrm{E}$ & $\ddot{O}$ & $\mathrm{E}$ & $\ddot{\mathrm{O}}$ & $\mathrm{E}$ & $\ddot{O}$ \\
\hline $\mathrm{m} 1$ & $.600^{* *}$ & $.754^{* *}$ & & & & & & \\
\hline $\mathrm{m} 2$ & $.431 * *$ & $.398^{* *}$ & & & & & & \\
\hline $\mathrm{m} 3$ & $.749 * *$ & $.855^{* *}$ & & & & & & \\
\hline $\mathrm{m} 4$ & $.859 * *$ & $.924 * *$ & & & & & & \\
\hline m5 & $.824 * *$ & $.929 * *$ & & & & & & \\
\hline $\mathrm{m} 6$ & $.871 * *$ & $.915^{* *}$ & & & & & & \\
\hline $\mathrm{m} 7$ & $.914 * *$ & $.933^{* *}$ & & & & & & \\
\hline $\mathrm{m} 8$ & $.830^{* *}$ & $.940^{* *}$ & & & & & & \\
\hline m9 & $.764 * *$ & $.826^{* *}$ & & & & & & \\
\hline m10 & $.809^{* *}$ & $.810^{* *}$ & & & & & & \\
\hline $\mathrm{m} 11$ & $.649 * *$ & $.718^{* *}$ & & & & & & \\
\hline $\mathrm{m} 12$ & $.766^{* *}$ & $.848^{* *}$ & & & & & & \\
\hline $\mathrm{m} 13$ & $.775^{* *}$ & $.895^{* *}$ & & & & & & \\
\hline $\mathrm{m} 14$ & $.710^{* *}$ & $.841 * *$ & & & & & & \\
\hline $\mathrm{m} 15$ & $.713^{* *}$ & $.799 * *$ & & & & & & \\
\hline $\mathrm{m} 16$ & & & $.484 * *$ & $.521 * *$ & & & & \\
\hline m17 & & & $.555^{* *}$ & $.701 * *$ & & & & \\
\hline m18 & & & $.726 * *$ & $.839 * *$ & & & & \\
\hline m19 & & & $.648^{* *}$ & $.797 * *$ & & & & \\
\hline $\mathrm{m} 20$ & & & $.805^{* *}$ & $.898^{* *}$ & & & & \\
\hline $\mathrm{m} 21$ & & & $.888 * *$ & $.947 * *$ & & & & \\
\hline $\mathrm{m} 22$ & & & $.883^{* *}$ & $.947 * *$ & & & & \\
\hline $\mathrm{m} 23$ & & & $.925^{* *}$ & $.956^{* *}$ & & & & \\
\hline $\mathrm{m} 24$ & & & $.893 * *$ & $.932 * *$ & & & & \\
\hline $\mathrm{m} 25$ & & & $.865 * *$ & $.905^{* *}$ & & & & \\
\hline $\mathrm{m} 26$ & & & $.854 * *$ & $.911 * *$ & & & & \\
\hline $\mathrm{m} 27$ & & & $.895^{* *}$ & $.933 * *$ & & & & \\
\hline $\mathrm{m} 28$ & & & $.836 * *$ & $.919 * *$ & & & & \\
\hline $\mathrm{m} 29$ & & & $.866 * *$ & $.918^{* *}$ & & & & \\
\hline m30 & & & $.838 * *$ & $.888^{* *}$ & & & & \\
\hline m31 & & & $.763 * *$ & $.771 * *$ & & & & \\
\hline $\mathrm{m} 32$ & & & $.791 * *$ & $.839 * *$ & & & & \\
\hline $\mathrm{m} 33$ & & & $.731 * *$ & $.766^{* *}$ & & & & \\
\hline $\mathrm{m} 34$ & & & $.747 * *$ & $.783^{* *}$ & & & & \\
\hline $\mathrm{m} 35$ & & & $.854 * *$ & $.920 * *$ & & & & \\
\hline $\mathrm{m} 36$ & & & $.812 * *$ & $.890 * *$ & & & & \\
\hline m37 & & & $.706^{* *}$ & $.827 * *$ & & & & \\
\hline m38 & & & $.907 * *$ & $.938 * *$ & & & & \\
\hline m39 & & & $.908^{* *}$ & $.952^{* *}$ & & & & \\
\hline $\mathrm{m} 40$ & & & $.869 * *$ & $.929 * *$ & & & & \\
\hline $\mathrm{m} 41$ & & & $.916^{* *}$ & $.919 * *$ & & & & \\
\hline $\mathrm{m} 42$ & & & $.909 * *$ & $.916^{* *}$ & & & & \\
\hline $\mathrm{m} 43$ & & & $.839 * *$ & $.939 * *$ & & & & \\
\hline $\mathrm{m} 44$ & & & $.779 * *$ & $.913^{* *}$ & & & & \\
\hline $\mathrm{m} 45$ & & & $.711 * *$ & $.812^{* *}$ & & & & \\
\hline $\mathrm{m} 46$ & & & & & $.673^{* *}$ & $.789 * *$ & & \\
\hline $\mathrm{m} 47$ & & & & & $.820^{* *}$ & $.852^{* *}$ & & \\
\hline $\mathrm{m} 48$ & & & & & $.602 * *$ & $.794 * *$ & & \\
\hline $\mathrm{m} 49$ & & & & & $.928 * *$ & $.921 * *$ & & \\
\hline m50 & & & & & $.820^{* *}$ & $.895^{* *}$ & & \\
\hline m51 & & & & & $.846^{* *}$ & $.890 * *$ & & \\
\hline m52 & & & & & $.833^{* *}$ & $.905^{* *}$ & & \\
\hline m53 & & & & & $.651^{* *}$ & $.838^{* *}$ & & \\
\hline m54 & & & & & & & $.775^{* *}$ & $.858^{* *}$ \\
\hline m55 & & & & & & & $.782^{* *}$ & $.895^{* *}$ \\
\hline $\mathrm{m} 56$ & & & & & & & $.841 * *$ & $.862^{* *}$ \\
\hline
\end{tabular}


Tablo 4. SİLKOL-R-OTV'nin ebeveyn ve öğretmen formu için DFA sonucunda elde edilen faktör yükleri (devami)

\begin{tabular}{|c|c|c|c|c|c|}
\hline & Sosyal Katılım & İfade Edici Dil & \multirow[t]{2}{*}{ Alıc1 Dil } & \multicolumn{2}{|c|}{ Taklit/Oyun } \\
\hline & $\mathrm{E}$ & $\mathrm{E} \quad \ddot{\mathrm{O}}$ & & $\ddot{O}$ & $\mathrm{E}$ \\
\hline $\mathrm{m} 57$ & & & & $.819 * *$ & $.894 * *$ \\
\hline $\mathrm{m} 58$ & & & & $.817 * *$ & $.917 * *$ \\
\hline m59 & & & & $.673 * *$ & $.859 * *$ \\
\hline $\mathrm{m} 60$ & & & & $.299 * *$ & $.334 * *$ \\
\hline $\mathrm{m} 61$ & & & & $.774 * *$ & $.750 * *$ \\
\hline $\mathrm{m} 62$ & & & & $.738^{* *}$ & $.830^{* *}$ \\
\hline $\mathrm{m} 63$ & & & & $.772 * *$ & $.840^{* *}$ \\
\hline $\mathrm{m} 64$ & & & & $.877 * *$ & $.896^{* *}$ \\
\hline m65 & & & & $.897 * *$ & $.893^{* *}$ \\
\hline m66 & & & & $.848^{* *}$ & $.922^{* *}$ \\
\hline $\mathrm{m} 67$ & & & & $.864 * *$ & $.932 * *$ \\
\hline m68 & & & & $.828^{* *}$ & $.904^{* *}$ \\
\hline m69 & & & & $.746^{* *}$ & $.761 * *$ \\
\hline $\mathrm{m} 70$ & & & & $.524 * *$ & $.503^{* *}$ \\
\hline
\end{tabular}

Tablo 4’te görüldüğü gibi, Sosyal Katılım alt ölçeğinde faktör yükleri ebeveyn formu için .431 (m2) ile .914 (m7) arasında ve öğretmen formu için .398 (m2) ile .940 (m8) arasında değişmektedir ve iki form için de tüm maddeler manidardır ( $\mathrm{p}<.01)$. İfade Edici Dil alt ölçeğinde faktör yükleri ebeveyn formu için .484 (m16) ile .925 (m23) arasında ve öğretmen formu için .521 (m16) ile .956 (m23) arasında değişmektedir ve iki form için de tüm maddeler manidardır $(\mathrm{p}<.01)$. Alıcı Dil alt ölçeğinde faktör yükleri ebeveyn formu için .651 (m53) ile .928 (m49) arasında ve öğretmen formu için .789 (m46) ile .921 (m49) arasında değissmektedir ve iki form için de tüm maddeler manidardır ( $\mathrm{p}<.01)$. Taklit/Oyun alt ölçeğinde faktör yükleri ebeveyn formu için 299 (m60) ile .897 (m65) arasında ve öğretmen formu için .334 (m60) ile .922 (m66) arasında değişmektedir. Diğer tüm alt testlere benzer biçimde iki form için de tüm maddeler manidardır $(\mathrm{p}<.01)$.

\section{Ölçüt geçerliği}

OSB olan çocukların erken sosyal etkileşim, dil ve iletişim becerilerinin değerlendirilmesi için geliştirilen Sosyal İletişim Kontrol Listesi-Revize-Okulöncesi Türkçe Versiyonu'nun ölçüt geçerliğine sahip olup olmadığına yanıt bulabilmek amacıyla yapılan, SİLKOL-R-OTV'nin dört alt faktörü ve Toplam Puan ebeveyn ve öğretmen formları puanları ile SOYÖ-2-OTF’nin beş alt faktör ve Toplam Puan ebeveyn ve öğretmen formları puanlarının korelasyonu incelenmiş ve sonuçlar Tablo 5 ve Tablo 6'da sunulmuştur. 
Tablo 5. SİLKOL-R-OTV ebeveyn formunun SOYÖ-2-OTF ile korelasyonu

\begin{tabular}{|c|c|c|c|c|c|c|c|}
\hline & & \multicolumn{6}{|c|}{ SOYÖ-2-OTF } \\
\hline & & SF & SB & SI & SM & SİTD & Toplam Puan \\
\hline \multirow{5}{*}{ 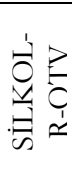 } & SK & $-.796^{* *}$ & $-.599 * *$ & $-.647 * *$ & $-.546^{* *}$ & $-.519 * *$ & $-.593 * *$ \\
\hline & İED & $-.860 * *$ & $-.492 * *$ & $-.415^{* *}$ & $-.313^{* *}$ &,$- 284 * *$ & $-.359 * *$ \\
\hline & $\mathrm{AD}$ & $-.794 * *$ & $-.489 * *$ & $-.473^{* *}$ & $-.436 * *$ &,$- 334 * *$ & $-.423 * *$ \\
\hline & TO & $-.837 * *$ & $-.570^{* *}$ & $-.523^{* *}$ & $-.456^{* *}$ &,$- 388 * *$ & $-.488 * *$ \\
\hline & Toplam Puan & $-.945^{* *}$ & $-.602 * *$ & $-.562 * *$ & $-.462 * *$ &,$- 408 * *$ & $-.500 * *$ \\
\hline
\end{tabular}

**p<.01; SİLKOL-R-OTV: Sosyal İletişim Kontrol Listesi-Revize-Okulöncesi Türkçe Versiyonu; E: Ebeveyn; Ö: Öğretmen; SK: Sosyal Katılım; İED: İfade Edici Dil; AD: Alıcı Dil; TO: Taklit/Oyun; SOYÖ-2-OTF: Sosyal Yanıtlayıcılık Ölçeği-2-Okul Öncesi Türkçe Formu; SF: Sosyal Farkındalık; SB: Sosyal Biliş; Sİ: Sosyal İletişim; SM: Sosyal Motivasyon; SİTD: Sınırlı İlgi Alanı ve Tekrarlayıcı Davranışlar

Tablo 5’te görüldügü gibi, ebeveynlerden toplanan verilere göre iki ölçeğin tüm alt ölçekler ve toplam puanları arasındaki ilişkiler manidardır $(\mathrm{p}<.01)$. SİLKOL-R-OTV'nin, SOYÖ-2-OTF'nin alt ölçekleri ile korelasyonları -.284 ile -.860 arasında değişirken, SİLKOL-R-OTV ölçek toplam puanı ile en yüksek ilişkinin SOYÖ-2-OTF’nin Sosyal Farkındalık (SF) alt ölçeği arasında olduğu görülmektedir ( $r=-.945, \mathrm{p}<.01)$. SİLKOL-R-OTV alt ölçeklerinin SOYÖ-2-OTF alt ölçekleri ile ilişkisi incelendiğinde korelasyon katsayılarının negatif yönde orta ve orta-yüksek düzeyde anlamlı olduğu ve tüm alt ölçek korelasyonlarının birbirleriyle ilişkili olduğu görülmektedir. Bu bulgular, ebeveyn formlarına göre çocukların SİLKOL-R-OTV puanları arttıkça, yani sosyal iletişim yeterlilikleri arttıkça SOYÖ-2-OTF puanlarının azaldığını, başka bir anlatımla iletişim bozukluklarının azaldığını göstermektedir.

Tablo 6. SİLKOL-R-OTV ögretmen formunun SOYÖ-2-OTF ile korelasyonu

\begin{tabular}{|c|c|c|c|c|c|c|c|}
\hline & & \multicolumn{6}{|c|}{ SOYÖ-2-OTF } \\
\hline & & $\mathrm{SF}$ & SB & SI & SM & SİTD & Toplam Puan \\
\hline \multirow{5}{*}{ 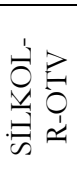 } & SK & $-.640 * *$ & $-.649 * *$ & $-.695 * *$ & $-.632 * *$ & $-.533 * *$ & $-.680 * *$ \\
\hline & IED & $-.537 * *$ & $-.565 * *$ & $-.544 * *$ & $-.468 * *$ & $-.359 * *$ & $-.521 * *$ \\
\hline & $\mathrm{AD}$ & $-.567 * *$ & $-.511 * *$ & $-.565 * *$ & $-.472 * *$ & $-.361 * *$ & $-.538 * *$ \\
\hline & $\mathrm{TO}$ & $-.600 * *$ & $-.612 * *$ & $-.601 * *$ & $-.540 * *$ & $-.439 * *$ & $-.604 * *$ \\
\hline & Toplam Puan & $-.619 * *$ & $-.632 * *$ & $-.637 * *$ & $-.558^{* *}$ & $-.449 * *$ & $-.621 * *$ \\
\hline
\end{tabular}

**p<.01; SİLKOL-R-OTV: Sosyal İletişim Kontrol Listesi-Revize-Okulöncesi Türkçe Versiyonu; E: Ebeveyn; Ö: Öğretmen; SK: Sosyal Katılım; IED: İfade Edici Dil; AD: Alıcı Dil; TO: Taklit/Oyun; SOYÖ-2-OTF: Sosyal Yanıtlayıclık Ölçeği-2-Okul Öncesi Türkçe Formu; SF: Sosyal Farkındalık; SB: Sosyal Biliş; Sİ: Sosyal İletişim; SM: Sosyal Motivasyon; SíTD: Sınırlı İlgi Alanı ve Tekrarlayıcı Davranışlar

Tablo 6'da görüldüğü gibi, öğretmenlerden toplanan verilere göre tüm alt ölçekler ve ölçek toplam puanları arasındaki ilişkiler manidardır $(\mathrm{p}<.01)$. SİLKOL-R-OTV'nin, SOYÖ-2-OTF'nin alt ölçekleri ile korelasyonları -.359 ile -.695 arasında değişirken SİLKOL-R-OTV ölçek toplam puanı ile en yüksek ilişkinin SOYÖ-2-OTF'nin Sosyal İletişim (SI) alt ölçeği arasında olduğu görülmektedir ( $r=-.695, \mathrm{p}<.01)$. SİLKOL-R-OTV alt ölçeklerinin SOYÖ-2-OTF alt ölçekleri ile ilişkisi incelendiğinde korelasyon katsayılarının negatif yönlü olduğu, orta düzeyde anlamlı olduğu ve tüm alt ölçek korelasyonlarının birbirleriyle ilişkili olduğu görülmektedir. Bu bulgular, öğretmen formlarına göre çocukların SİLKOL-R-OTV puanları artıkça, yani sosyal iletişim yeterlilikleri 
arttıkça SOYÖ-2-OTF puanlarının azaldığını, başka bir anlatımla iletişim bozukluklarının azaldığını göstermektedir.

\section{Güvenirlik Analizleri}

\section{İ̧ tutarl1k katsayısı}

SİLKOL-R-OTV'nin güvenirliğini incelemek amacıyla, kontrol listesinin iç tutarlılı̆̆ını saptamak için Cronbach alfa iç tutarlılık katsayısı kullanılmıştır. Çalışma kapsamında SİLKOL-R-OTV'nin alt ölçekleri ve toplam puanları için, ebeveynlerden ve öğretmenlerden elde edilen verilerle Cronbach alfa güvenirlik katsayıları hesaplanmış ve sonuçlar Tablo 7'de verilmiştir.

Tablo 7. SİLKOL-R-OTV güvenirlik katsaylları

\begin{tabular}{lcc}
\hline SILLKOL-R-OTV & $\mathrm{E}$ & Oे \\
\hline SK & .927 & .952 \\
IED & .968 & .979 \\
AD & .889 & .933 \\
TO & .945 & .957 \\
Toplam & .983 & .988 \\
\hline
\end{tabular}

SİLKOL-R-OTV: Sosyal İletişim Kontrol Listesi-Revize-Okulöncesi Türkçe Versiyonu; SK: Sosyal Katılım; İED: İfade Edici Dil; AD: Alıcı Dil; TO: Taklit/Oyun; E: Ebeveyn; Ö: Öğretmen; E/Orj: Ebeveyn/Orijinal Form; T/Orj: Terapist/Orijinal Form

Tablo 7'de görüldüğü gibi SİLKOL-R-OTV Cronbach alfa iç tutarlılık katsayısı toplam puanı ebeveynler için .983 iken öğretmenler için .988'dir. Hem ebeveyn hem de öğretmen formlarında tüm alt testler için güvenirlik katsayılarının .80’in üzerinde olduğu görülmektedir.

\section{Değerlendirmeciler arası güvenirlik}

$\mathrm{Bu}$ çalışmada değerlendirmeciler arası güvenirliğin belirlenmesi amacıyla SİLKOL-R-OTV'nin ebeveyn ve öğretmen formlarının korelasyonları da incelenmiştir. Korelasyon analizlerinin sonuçları Tablo 8'de sunulmuştur.

Tablo 8. SİLKOL-R-OTV'nin ebeveyn ve öğretmen formlarının korelasyonları

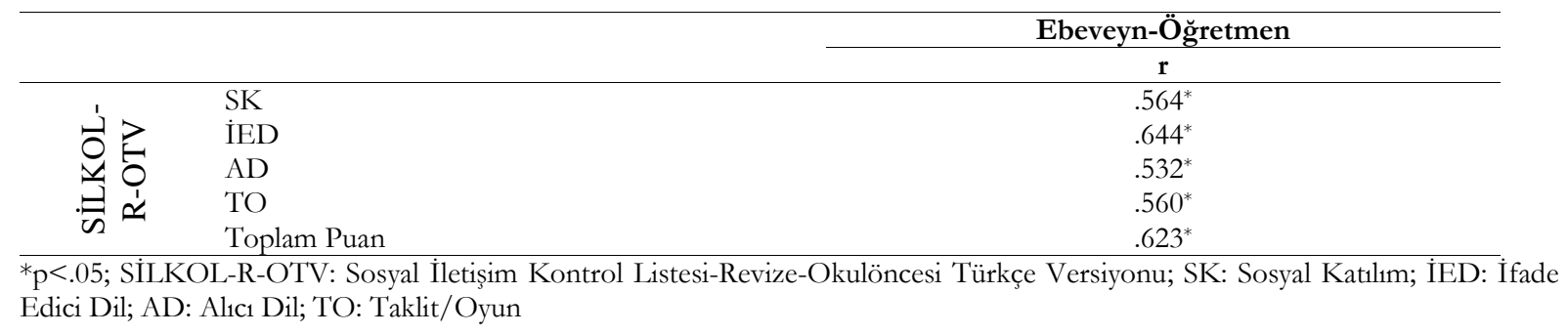

Tablo 8'de görüldüğü gibi, SİLKOL-R-OTV'nin alt ölçeklerinin ebeveyn ve öğretmen formları arasındaki ilişkiler manidardır $(\mathrm{p}<.01)$. SİLKOL-R-OTV ebeveyn formu ile öğretmen formunun alt ölçekleri arasındaki korelasyonlar, .532 ile .644 arasında değişmektedir. SİLKOL-R-OTV’nin 
ebeveyn ve öğretmen formları alt ölçeklerindeki korelasyonlarda en yüksek ilişkinin İfade Edici Dil (IED) alt alanında olduğu görülmektedir $(\mathrm{r}=.644, \mathrm{p}<.01)$.

\section{SONUÇ ve TARTIŞMA}

Bu araştırma SİLKOL-R-OTV'nin Türkçeye uyarlanması ve uyarlanan ölçeğin Türkçe formunun geçerlik ve güvenirlik analizlerinin yapılması amacıyla yürütülmüştür. Ölçeğin Türkçe formunun yap1 geçerliğinin belirlenmesi amacıyla DFA yapılmış ve analizler sonucunda ölçeğin özgün formuna benzer biçimde dört faktörlü bir yapıdan oluştuğu bulunmuştur. DFA analizlerinde uyum iyiliğine ilişkin kestirimler göz önüne alındığında, hem öğretmenler tarafindan doldurulan formlar (X2/sd=2.19, RMSEA: 0.069; CFI: 0.954, TLI: 0.953) hem ve ebeveynler tarafindan doldurulan formlar (X2/sd=2.23, RMSEA: 0.068; CFI: 0.916; TLI: 0.913) için dört faktörlü yapinın uyum indekslerinin iyi düzeyde olduğu bulunmuştur. Dolayısı ile araştırmanın sonucunda SİLKOL-ROTV'nin dört faktörlü orijinal yapısının Türk kültüründe de doğrulandığı sonucuna ulaşılmıştır.

DFA sonuçları, ölçekteki alt testleri oluşturan maddelerin tümünün özgün ölçeğe benzer biçimde aynı alt ölçekler altında toplandığını, tüm maddelerin alt ölçek toplam puanlarına katkısının anlamlı olduğunu göstermiştir. Doğrulayıcı faktör analizinde .30 ile .59 arası faktör yük değerleri orta düzey, .60 ve üzeri faktör yük değerleri ise yüksek düzey olarak kabul edilmektedir (Büyüköztürk, 2002). Analizler sonucunda bir madde dişında tüm maddelerin faktör yüklerinin .30’un üstünde olduğu, sadece ebeveynler tarafından doldurulan formda 60'nc1 maddenin faktör yükünün .299 olduğu bulunmuştur. Bu maddeye ilişkin faktör yükü, ebeveyn formu için .299, öğretmen formu için ise .334 değerleri ile yüklenmiştir. Bu madde "Çocuğunuz, oyuncakları keşfedici tarzda (dokunma, ağzına alma, koklama, bakma gibi) kullanır mı?” sorusunu içermektedir. Bu maddenin ebeveyn formunda manidar da olsa düşük faktör yük değerine sahip olmasının nedeninin, ebeveynlerin bir kısmının bu davranışı oyundan ziyade tekrarlayıcı davranış olarak algılamış olabileceklerinden kaynaklandığ1 düşünülmektedir. Özellikle ağıza alma ve koklama davranışları keşfedici ve manipülatif oyunlar içinde ele alınırken (Ingersoll ve Dvortcsak, 2010), nesneleri atipik biçimde ağza alma ve koklama aynı zamanda tekrarlayıcı davranışlar olarak da ortaya çıkabilmektedir (Bodfish, 2007, 2011). Ebeveynlerin bu iki davranışı ayırt etmekte zorlanma olasılıklarının bu faktörün yükünü etkileyebileceği düşünülmektedir. Bu maddenin t değerinin anlamlı olması (madde 60 için $\mathrm{t}_{\mathrm{i}}>1.96, \mathrm{p}_{\mathrm{i}}<.05$ ) nedeniyle (Çokluk vd., 2012), uzman görüşleri de alınarak (Crocker ve Algina, 2008) maddenin araçta kalması yönünde karar verilmiştir. Bununla beraber tüm DFA sonucuna bakıldığında, ebeveyn ve öğretmen formlarında faktör yük değerlerinin orta ve yüksek düzeylerde olması, sonuçların başarılı olduğunu ve kontrol listesindeki tüm maddelerin birlikte ait 
oldukları alt alanı ölçtüğünü göstermektedir (Alpar, 2010). Ölçeğin orijinal geçerlik güvenirlik çalışmasında (Ingersoll ve Wainer, 2013) DFA yapılmaması nedeniyle bu çalışmanın DFA sonuçları ve faktör yükleri ölçeğin asıl formunun yapı geçerliği sonuçları karşılaştırılamamıştır.

SİLKOL-R-TV'nin ölçüt geçerliğini belirlemek için kontrol listesinden elde edilen puanlar ile SOYÖ-2-OTF puanları arasındaki ilişkiler incelenmiştir. Analizler sonucunda iki araçtan elde edilen puanlar arasındaki korelasyon katsayılarının orta düzeyde anlamlı olduğu ve tüm alt ölçek korelasyonlarının birbirleriyle ilişkili olduğu bulunmuştur. Bu korelasyon sonuçları, SİLKOL-ROTV ebeveyn ve öğretmen formunun ölçüt geçerliğine sahip olduğunun bir göstergesi olarak yorumlanabilir. SOYÖ-2-OTF, DSM-5 ile uyumlu olan ve çocuklarda görülen sosyal yanıtlayıc1lı bozukluklarının derecesini ve sınırlı ilgi alanı ve tekrarlayıcı davranışların derecesini ölçen bir değerlendirme aracıdır (Constantino ve Gruber, 2012). SOYÖ-2-OTF'nin, Sosyal Farkındalık, Sosyal Biliş, Sosyal İletişim, Sosyal Motivasyon alt ölçek puanları ile SİLKOL-R-OTV alt alanları arasında orta ve yüksek düzeyde negatif korelasyon olması çocukların sosyal katılım, alıcı-ifade edici dil ve taklit/oyun puanları arttıkça sosyal yanıtlayıcılıkta yaşadıkları güçlüklerin azaldığını göstermektedir. Sınırlı İlgi Alanları ve Tekrarlayıcı Davranışlar (SİTD) alt ölçeği ile SİLKOL-ROTV alt alanları arasındaki korelasyonlar ise sosyal iletişim davranışlarında iyi puan alan çocukların, sınırlı ilgi alanı ve tekrarlayıcı davranışlar alt ölçeğinden düşük puan aldıklarını göstermektedir. Bu bulgular, kontrol listesinin orijinal formunun geçerlik güvenirlik çalışmasıyla da tutarlılık göstermektedir. Orijinal formun geçerlik güvenirlik çalışmasında, ebeveynler tarafindan doldurulan SİLKOL-R alt alanları ile SOYÖ-2 toplam puanları arasında -.36 ile -.57 arasında değişen korelasyon katsayıları olduğu, öğretmenler tarafindan doldurulan SİLKOL-R formunun alt ölçekleri ile SOYÖ-2 toplam puanı arasındaki korelasyon katsayılarının ise -.57 ile -.65 arasında farklılaştığı bulunmuştur (Wainer vd., 2017). Bununla birlikte Wainer ve diğerlerinin yaptıkları çalışmada SOYÖ-2'nin alt ölçekleri ile ilişkilere ayrı ayrı bakılmamış, sadece toplam puanla ilişkiler incelenmiştir. Bu araştırmada ise tüm alt ölçeklerin birbirleri ile ilişkileri incelenmiş ve Türkçe formu için korelasyon katsayılarının orijinal form çalışmasına göre daha yüksek olduğu bulunmuştur.

SİLKOL-R-OTV ölçeğinin güvenirliğine ilişkin analizler incelendiğinde hem öğretmenler tarafından hem de ebeveynler tarafindan doldurulan formların tüm alt ölçekler ve toplam ölçek puanı için Cronbach Alpha değerlerini .80'nin üzerinde olduğu belirlenmiştir. Cronbach Alpha iç tutarll1ık katsayısı 0 ile 1 arasında bir dağglım göstermektedir ve bu değerinin 0.00 ile 0.40 arasında olması ölçeğin güvenilir olmadığını, 0.41 ile 0.60 aralığında olması düşük düzeyde güvenilir olduğunu, 0.61 ile 0.80 aralığında olması orta düzeyde güvenilir olduğunu, 0.81 ile 1.00 aralığında olması ise yüksek düzeyde güvenilir olduğunu göstermektedir (Alpar, 2010). Ebeveynlerin 
doldurduğu SİLKOL-R-OTV formları için güvenirlik katsayılarının .889 ile .945 arasında olduğu bulunmuştur. Öğretmenler tarafindan doldurulan formlar için ise, katsayıların daha yüksek (.933 ile .979 arasında) olduğu görülmüştür. Bu durumun, öğretmenlerin çocukların performanslarını raporlarken ebeveynlere göre daha objektif olma ihtimallerinden kaynaklandığı düşünülmektedir. Çalışmanın sonucunda kontrol listesinin tüm alt ölçeklerinin ve ölçeğin tümünün güvenirlik katsayılarının yüksek derecede olduğu ifade edilebilir.

SİLKOL-R'nin orijinal formunun geçerlik güvenirlik çalışmasında ebeveynlerin doldurduğu formlarda toplam puan için Cronbach alfa iç tutarl11k katsayısı .967 olduğu bulunmuştur. Ebeveynlerin doldurdukları formlar için iç tutarlılık katsayısının Sosyal Katılım alt boyutunda .870, Dil alt boyutunda .959, Taklit/Oyun alt boyutunda .891 olduğu görülmüştür. Terapistler tarafindan doldurulan formlarda ise iç tutarlılık katsayısının Sosyal Katılım alt alanı için .870, Dil alt alanı için .958 ve Taklit/Oyun alt alanı için .714 olduğu, toplam puan için ise .960 olduğu bulunmuştur (Wainer vd., 2017). Bu açıdan bakıldığında Türkçeye uyarlanmış olan formun iç tutarlılık katsayılarının orijinal kontrol listesi formuyla benzer olduğu, bununla birlikte alt testler için iç tutarll1ık katsayılarının Türkçe formda orijinal forma göre daha yüksek olduğu ve ölçeğin Türkçe formunun yüksek derecede güvenilir olduğu söylenebilir.

Değerlendirmeciler arası güvenirlikte SİLKOL-R-OTV için ebeveynler ve öğretmenlerin doldurdukları formlar arasındaki korelasyona bakılmıştır. Ebeveynler ve öğretmenler tarafindan doldurulan formlardan elde edilen alt ölçek ve toplam ölçek puanları arasındaki ilişkinin orta düzeyde olduğu bulunmuştur. Ebeveynler ve öğretmenlerden elde edilen puanlar arası anlamlı ilişkiler olması maddelerin açık ve anlaşılır olduğunun bir göstergesidir. Sonuç olarak, ebeveyn formları ile öğretmen formları arasında anlamlı pozitif korelasyon olması SİLKOL-R-OTV'nin ebeveyn ve öğretmen formunun ölçüt geçerliğine sahip olduğunun bir göstergesi olarak yorumlanabilir (Büyüköztürk, 2011).

Sonuç olarak tüm analizler göz önüne alındığında OSB olan okul öncesi dönem çocukların sosyal etkileşim, iletişim ve dil becerilerinin değerlendirilmesinde SİLKOL-R-OTV'nin geçerli ve güvenilir bir araç olduğu sonucuna ulaşılmıştır. OSB olan çocukların sosyal etkileşim, iletissim ve dil becerilerini değerlendirmede ebeveyn ve öğretmenlerle görüşme yoluyla uygulanabilen bu aracın kısa olması ve kolay doldurulması nedeniyle alandaki araştırmacılar tarafından rahatlıkla kullanılabileceği düşünülmektedir. Ek olarak kontrol listesindeki maddelerin, dil, sosyal etkileşim ve iletişim becerilerinin gelişimsel sırasına uygun sıralanmış olması ve aracın uluslararası alanyazında daha önce de hem müdahaleyi planlamada hem de gelişimi izlemede kullanılması (Ingersoll ve 
Dvortcsak, 2010) nedeniyle, aracın uyarlanmasının ülkemizde OSB olan çocuklarla çalışan uygulamacılar için de yararlı olacağı düşünülmektedir.

Bu araştırmanın bazı güçlü yönleri ve sınırllıkları bulunmaktadır. Güçlü yönlerinden ilki tüm çocuklar için hem öğretmenlerden hem de ebeveynlerden veri toplanmış olması ve bu iki grubun sonuçlarının tutarlı olmasıdır. İkincisi katılımcı çocukların tanılarının GOBDÖ-2-TV ile doğrulanmış olmasıdır. Öğretmen ve ebeveynler tarafından doldurulan sosyal iletişim ölçeklerinin ölçüt geçerliliklerinin gözleme dayalı verilerle konfirme edilmiş olmaması, GOBDÖ-2-TV'nin DSM-IV ölçütlerine göre hazırlanan bir ölçek olması nedeni ile OSB tanısını doğrularken DSM-5 ölçütlerine dayalı bir aracın kullanılmamış olması ile bu araştırmanın sınırlılıklarıdır. Bu araştırmanın başka bir sınırlılığ1 örneklem grubunun büyüklügüdür. Araştırmanın katılımcıları 294 çocuktan oluşmaktadır. Alanyazındaki ölçek çalışmalarında örneklem grubunun, ölçekteki toplam madde sayısının 5 katı olması önerilmektedir (MacCallum, Widaman, Zhang ve Hong, 1999; Erkuş, 2012). Ancak alanyazındaki bir başka kaynakta ise, örneklem büyüklügüüün 300 kişi olmasının analizler için yeterli olduğu belirtilmektedir (Tabachnick ve Fidell, 2013). Bu araştırmanın katılımcıları 294 çocuktan oluşmaktadır ve dolayısıyla bu sayının 300 kişiye yakın olması nedeniyle analizler için yeterli olduğu düşünülmektedir. Bununla birlikte daha büyük bir örneklem ile tekrar çalışma yapılmasının kontrol listesinin geçerlik güvenirliğine ilişkin güçlü bir kanıt oluşturacağı düşünülmektedir. Bunun yanı sıra, SİLKOL-R-OTV'den alınan puanların gözleme dayalı ölçümlerle ilişkilerinin incelenmesine yönelik çalışmalar yapılabilir ki böyle bir çalışma, kontrol listesinin geçerlik bulgularını zenginleştirecektir. Benzer bir biçimde, bu kontrol listesinin alt boyutları üzerinde durularak yeni araçlar geliştirilebilir ya da kontrol listesine ilişkin DFA çalışmaları benzer başka gruplar için de uygulanarak kontrol listesinin geçerliğine katkıda bulunulabilir.

Tüm bu sınırlılıklarla birlikte, SİLKOL-R-OTV’nin küçük yaş OSB olan çocukların ebeveynlerinin ve öğretmenlerinin, çocukların gelişimini izlemede kullanabilecekleri önemli bir araç olduğu düşünülmektedir. Ebeveynler, OSB olan çocuklarının erken sosyal etkileşim becerilerinde nasıl performans gösterdiklerini görmede ve aynı zamanda çocuklarının erken sosyal etkileşim becerilerini hedefleyen müdahale programlarının çocuklarına olan katkısın izlemede SİLKOL-ROTV'den yararlanabilirler. Uygulamacılar ise, OSB olan öğrencilerinin sosyal katılım, alıcı dil, ifade edici dil, taklit ve oyun alt alanlarındaki performansı hakkında bilgi edinmede bu kontrol listesinden yararlanabilirler. Bunun yanı sıra bu kontrol listesi, uzmanların çocukların daha önemli ihtiyaçlarına yönelik müdahale programları geliştirmelerine yardımcı olabilecek ve uyarlamalar yapmalarına fırsat verecektir. 


\section{KAYNAKÇA}

Acarlar, F. (2019). Dil becerilerinin değerlendirilmesi. F. Acarlar \& Ö. Diken (Ed.), Yetersizliği olan cocuklarn dil ve iletisim becerilerinin desteklenmesi içinde (ss. 181-199). Ankara: Pegem Akademi.

Aksu-Koç A, Acarlar F, Küntay A, et al. (2008). TCDI (TIGGE)-Measurement and evaluation of early communicative competence of Turkish children: The adaptation of MacArthur-Bates Communicative Development Inventory (CDI) into Turkish. 12th Congress of the International Clinical Phonetics and Linguistics Association. 25 -28 June , 2008. İstanbul, Türkiye.

Alak, G. (2019). Söz öncesi dil gelişimi. F. Acarlar \& Ö. Diken (Ed.), Yetersiz̨liği olan çocuklarn dil ve iletişim becerilerinin desteklenmesi içinde (ss. 29-55). Ankara: Pegem Akademi.

Alpar, R. (2010). Uygulamal istatistik ve gẹcerlik, güvenirlik. Ankara: Detay Yayınc1lik.

American Psychiatric Association (2013). Diagnostic and statistical manual of mental disorders (5th ed.). Arlington, VA: American Psychiatric Publishing.

Baio, J., Wiggins, L., Christensen, D. L., Maenner, M. J., Daniels, J., Warren, Z., ... \& Durkin, M. S. (2018). Prevalence of autism spectrum disorder among children aged 8 years-autism and developmental disabilities monitoring network, 11 sites, United States, 2014. MMWR Surveillance Summaries, 67(6), 1. doi: 10.15585/mmwr.ss6706a1

Bakkaloğlu, H., Ökcün-Akçamuş, M. C.., Demir, Ş., Bahap-Kudret, Z. ve Yalçın, S., (2019). Sosyal Yanttlaynchlk Ölçeği-2 Okulöncesi Türkçe Formu'nun Türk kültürü̈ne uyarlanması: Geçerlike ve Güvenirlik Çalışması. Yayınlanmamış araştırma raporu.

Bodfish, J. W. (2007). Stereotypy, self-injury, and related abnormal repetitive behaviors. In J. W. Jacobson, J. A. Mulick \& J. Rojahn (Eds.), Handbook of intellectual and developmental disabilities (pp. 481-505). Boston, MA: Springer.

Bodfish, J. W. (2011). Repetitive behaviors in individuals with autism spectrum disorders. In D. Amaral, G. Dawson \& D. Geschwind (Eds.), Autism Spectrum Disorders (pp. 200-212). NC: Oxford University Press.

Bornstein, M. H., Haynes, M. O., \& Painter, K. M. (1998). Sources of child vocabulary competence: A multivariate model. Journal of Child Language, 25(2), 367-393. doi: $10.1017 /$ S0305000998003456

Brady, N. C., \& Keen, D. (2016). Individualized assessment of prelinguistic communication. In D. Keen, Meadan. H, N. C. Brady \& J. W. Halle (Eds.), Prelinguistic and minimally verbal communicators on the autism spectrum (pp. 101-119). Springer, Singapore.

Brown, T. A. (2014). Confirmatory factor analysis for applied research. New York,NY: Guilford Publications.

Büyüköztürk, Ş. (2002). Faktör analizi: Temel kavramlar ve ölçek geliştirmede kullanımı. Kuram ve Uygulamada Eğitim Yönetimi Dergisi, 8(4), 470-483. Erişim adresi: https://dergipark.org.tr/download/article-file/108451

Büyüköztürk, Ş. (2011). Sosyal bilimler için veri analizi el kitabr: Istatistik, arastırma deseni SPSS uygulamalar ve yorum. Ankara: Pegem Yayıncilık.

Byrne, B. M. (2016). Structural equation modeling with AMOS: Basic concepts, applications, and programming. New York, NY: Routledge.

Charman, T. (2004). Matching preschool children with autism spectrum disorders and comparison children for language ability: Methodological challenges. Journal of Autism and Developmental Disorders, 34(1), 59-64. doi: 10.1023/B:JADD.0000018075.77941.60 
Charman, T., Taylor, E., Drew, A., Cockerill, H., Brown, J., \& Baird, G. (2005). Outcome at 7 years of children diagnosed with autism at age 2: Predictive validity of assessments conducted at 2 and 3 years of age and pattern of symptom change over time. Journal of Child Psychology \& Psychiatry, 46(5), 500-513. doi: 10.1111/j.1469-7610.2004.00377.x

Chawarska, K., \& Volkmar, F. (2005). Autism in infancy and early childhood. In F. Volkmar, R. Paul, A. Klin, \& D. J. Cohen (Eds.), Handbook of autism and pervasive developmental disorders (pp. 223-246). Hoboken, NJ: John Wiley \& Sons

Condouris, K., Meyer, E., \& Tager-Flusberg, H. (2003). The relationship between standardized measures of language and measures of spontaneous speech in children with autism. American Journal of Speech-Language Pathology, 12, 349-358. doi: 10.1044/10580360(2003/080)

Constantino, J. N. (2002). The Social Responsiveness Scale. Los Angeles, CA: Western Psychological Services.

Constantino, J. N., \& Gruber, C. P. (2012). Social Responsiveness Scale-Second Edition (SRS-2). Torrance: Western Psychological Services.

Crocker, L., \& Algina, J. (2008). Introduction to classical and modern test theory. Mason, Ohio: Cengage Learning.

Çokluk, Ö., Şekercioğlu, G., \& Büyüköztürk, Ș. (2012). Sosyal bilimler için çok değģ̧kenli istatistik: SPSS ve LISREL uygulamalar (Vol. 2). Ankara: Pegem Akademi.

Diken, I. H., Ardıç, A., Diken, Ö., \& Gilliam, J. E. (2012). Exploring the validity and reliability of Turkish Version of Gilliam Autism Rating Scale-2: Turkish standardization study. Eğitim ve Bilim, 37(166), 318-328. Retrieved from: http://egitimvebilim.ted.org.tr

Erdoğan, Y., Bayram, S., \& Deniz, L. (2007). Web based instruction attitude scale: Explanatory and confirmatory factor analyses. Journal of Human Sciences, 4(2), 1-14. Retrieved from: https://www.j-humansciences.com/ojs/index.php/IJHS/article/view/335/247

Erkuş, A. (2012). Psikolojide ölçme ve ölçek geliştirme. Ankara: Pegem Akademi Yayınları.

Fombonne, E. (2009). Epidemiology of pervasive developmental disorders. Pediatric Research, 65(6), 591-598. doi: 10.1203/PDR.0b013e31819e7203

George, D., \& Mallery, P. (2010). SPSS for Windows step by step: A simple study guide and reference (10th ed). Boston, MA: Pearson.

Gernsbacher, M. A., Geye, H. M., \& Weismer S. E. (2005). The role of language and communication impairments within autism. In P. Fletcher \& J. C. Miller (Eds.), Language disorders and developmental theory (pp. 73-93). Philadelphia, PA: John Benjamins

Gilliam, J. E. (2006). Gilliam autism rating scale: Second edition. Austin, TX.: PRO-ED

Hooper, D., Coughlan, J., Mullen, M. (2008). Structural Equation Modelling: Guidelines for Determining Model Fit. Electronic Journal of Business Research Methods, 6(1), 53-60. Retrieved from: http://www.ejbrm.com/issue/download.html?idArticle=183

Ingersoll, B., \& Dvortcsak, A. (2010). Teaching social communication: A practitioner's guide to parent training for children with autism. New York, NY: Guilford Press.

Ingersoll, B., \& Wainer, A. (2013). Pilot study of a school-based parent training program for preschoolers with ASD. Autism: The International Journal of Research and Practice, 17(4), 434448. doi: 10.1177/1362361311427155

Kline, R. B. (2015). Principles and practice of structural equation modeling. New York, NY: Guilford publications. 
MacCallum, R. C., Widaman, K. F., Zhang, S., \& Hong, S. (1999). Sample size in factor analysis. Psychological Methods, 4(1), 84. Retrieved from http://citeseerx.ist.psu.edu/viewdoc/download? doi=10.1.1.536.6317\&rep=rep1\&type $=$ pdf

Marshall, C., \& Rossman, G. B. (2016). Designing qualitative research. Singapore: Sage publications.

Meyers, L. S., Gamst, G., \& Guarino, A. J. (2006). Multiple Regression. In Applied multivariate research: Design and interpretation (pp.147-196). Thousand Oaks, CA: Sage Publications

Ökcün-Akçamuş, M. Ç. (2016). Otizm spektrum bozukluğu olan çocukların sosyal iletişim becerileri ve dil gelişim özellikleri. Ankara Üniversitesi Eğitim Bilimleri Fakültesi Özel Eğitim Dergisi, 17(2), 163-192. doi: 10.21565/ozelegitimdergisi.246293

Paul, R. (2007). Communication and its development in autism spectrum disorders. In F. R. Volkmar (Ed.), Autism and pervasive developmental disorders (pp. 129-155). New York, NY: Cambridge University Press.

Paul, R. (2008). Communication development and assessment. In K. Chawarska, A. Klin, \& F. R. Volkmar (Eds.), Autism spectrum disorders in infants and toddlers (pp. 76-103). New York, NY: The Guilford Press.

Paul, R., \& Fahim, D. (2014). Assessing communication in autism spectrum disorders. In R. A., Volkmar, R. Paul, J. S., Rogers \& A. K., Pelphrey (Eds.), Handbook of autism and pervasive developmental disorders (pp. 673-695). New York, NY: John Wiley.

Schermelleh-Engel, K., Moosbrugger, H., \& Müller, H. (2003). Evaluating the fit of structural equation models: Tests of significance and descriptive goodness-of-fit measures. Methods of Psychological Research Online, 8(2), 23-74. doi: 10.1.1.509.4258\&rep=rep1\&type=pdf

Sigman, M., \& McGovern, C. (2005). Improvement in cognitive and language skills from preschool to adolescence in autism. Journal of Autism and Developmental Disorders, 35(1), 15-23. doi: 10.1007/s10803-004-1027-5

Siller, M., \& Sigman, M. (2002). The behaviors of parents of children with autism predict the subsequent development of their children's communication. Journal of Autism and Developmental Disorders, 32(2), 77-89. doi: 10.1023/A:1014884404276

Stone, W., \& Yoder, P. J. (2001). Predicting spoken language level in children with autism spectrum disorders. Autism, 5(4), 341-361. doi: 10.1177/1362361301005004002

Tabachnick, B. G. \& Fidell, L. S. (2013). Using multivariate statistics (6th ed.). New York, NY: Pearson

Tomasello, M., \& Mervis, C. B. (1994). The instrument is great, but measuring comprehension is still a problem. Monographs of the Society for Research in Child Development, 59(5), 174-179. doi: 10.1111/j.1540-5834.1994.tb00186.x

Trembath D., \& Iacono T. (2016). Standardized assessment of prelinguistic communication. In D. Keen, H. Meadan, N. Brady, \& J. Halle (Eds.), Prelinguistic and minimally verbal communicators on the autism spectrum (pp. 75-100). Singapore: Springer.

Wainer, A. L., Berger, N. I., \& Ingersoll, B. R. (2017). Brief report: The preliminary psychometric properties of the Social Communication Checklist. Journal of Autism and Developmental Disorders, 47(4), 1231-1238. doi: 10.1007/s10803-016-3026-8

Wilkinson, K. M. (1998). Profiles of language and communication skills in autism. Mental Retardation and Developmental Disabilities Research Reviews, 4(2), 73-79. Doi: 10.1002/(SICI)1098-2779(1998)4:2<73::AID-MRDD3>3.0.CO;2-Y 